\title{
Protection of the Blood-Brain Barrier by Pentosan Against Amyloid- $\beta$-Induced Toxicity
}

\author{
Mária A. Deli ${ }^{\mathrm{a}, *}$, Szilvia Veszelka ${ }^{\mathrm{a}}$, Boglárka Csiszár $^{\mathrm{a}}$, Andrea Tóth $^{\mathrm{a}}$, Ágnes Kittel $^{\mathrm{b}}$, Mária Csete $^{\mathrm{c}}$, \\ Áron Sipos ${ }^{\mathrm{c}}$, Anikó Szalai ${ }^{\mathrm{c}}$, Lívia Fülöp ${ }^{\mathrm{d}}$, Botond Penke ${ }^{\mathrm{d}}$, Csongor S. Ábrahám ${ }^{\mathrm{a}}$ and Masami Niwa ${ }^{\mathrm{e}}$ \\ ${ }^{a}$ Laboratory of Molecular Neurobiology, Institute of Biophysics, Biological Research Center of the Hungarian \\ Academy of Sciences, Szeged, Hungary \\ ${ }^{\mathrm{b}}$ Institute of Experimental Medicine, Hungarian Academy of Sciences, Budapest, Hungary \\ ${ }^{\mathrm{c}}$ Department of Optics and Quantum Electronics, University of Szeged, Szeged, Hungary \\ ${ }^{\mathrm{d}}$ Department of Medical Chemistry, University of Szeged, Szeged, Hungary \\ ${ }^{\mathrm{e}}$ Department of Pharmacology 1, Nagasaki University Graduate School of Biomedical Sciences, Nagasaki, Japan
}

Handling Associate Editor: William Banks

Accepted 20 July 2010

\begin{abstract}
Endothelial cells of brain capillaries forming the blood-brain barrier play an important role in the pathogenesis and therapy of Alzheimer's disease. Amyloid- $\beta(\mathrm{A} \beta)$ peptides are key pathological elements in the development of the disease. A blood-brain barrier model, based on primary rat brain endothelial cells was used in which the barrier properties were induced by glial cells. The effects of amyloid peptides have been tested on cell viability and barrier functions. A $\beta$ showed toxic effects on primary rat brain endothelial cells measured by MTT dye conversion and the lactate dehydrogenase release. Morphologically cytoplasmic vacuolization, disruption of the structure of cytoplasmic organelles and tight junctions could be observed in brain endothelial cells. Treatment with $\mathrm{A} \beta_{1-42}$ decreased the electrical resistance, and increased the permeability of brain endothelial cell monolayers for both fluorescein and albumin. Serum amyloid $\mathrm{P}$ component which stabilizes $\mathrm{A} \beta$ fibrils in cortical amyloid plaques and cerebrovascular amyloid deposits significantly potentiated the barrier-weakening effect of $\mathrm{A} \beta_{1-42}$. Sulfated polysaccharide pentosan could decrease the toxic effects of $\mathrm{A} \beta$ peptides in brain endothelial cells. It could also significantly protect the barrier integrity of monolayers from damaging actions of peptides. Pentosan modified the size, and significantly decreased the number of amyloid aggregates demonstrated by atomic force microscopy. The present data further support the toxic effects of amyloid peptides on brain endothelial cells, and can contribute to the development of molecules protecting the blood-brain barrier in Alzheimer's disease.
\end{abstract}

Keywords: Amyloid- $\beta$, blood-brain barrier, brain endothelial cells, glia, pentosan polysulfate, permeability, rat, serum amyloid P component

\footnotetext{
${ }^{*}$ Correspondence to: Mária A. Deli, M.D., Ph.D., Laboratory of Molecular Neurobiology, Institute of Biophysics, Biological Research Center of the Hungarian Academy of Sciences, Temesvári krt. 62., H-6726 Szeged, Hungary. Tel.: +36 62 599602; Fax: +36 62 433133; E-mail: deli@brc.hu.
}

\section{INTRODUCTION}

Alzheimer's disease (AD) is the most widespread form of dementias. In the European Union, 50-70\% of dementias are diagnosed as AD and the number of patients is over 7 million [1]. Despite intense research efforts there is still no effective therapy for AD. 
Recent findings indicate that neurovascular mechanisms contribute to cognitive decline and neurodegeneration in AD [2-6]. Decreased clearance of amyloid$\beta(\mathrm{A} \beta)$ across the blood-brain barrier (BBB), damaged angiogenesis, dysfunction of the cerebrovascular system all contribute to neurovascular uncoupling, brain hypoperfusion, and neurovascular inflammation $[4,5$, 7]. The BBB is indispensable for creating and maintaining the homeostasis of the central nervous system (CNS), therefore BBB dysfunction leads to disturbed homeostasis, neuronal dysfunction, and secondary neuronal loss $[4,5,8]$. It has also become clear that even subtle functional changes at the BBB without morphological alterations can lead to severe and lasting neurological dysfunction $[3,5]$.

The BBB is increasingly considered as a target of new therapeutical approaches in neurodegenerative disorders, especially in $\mathrm{AD}[5,8]$. In addition to production of the peptide, transport of $\mathrm{A} \beta$ across the $\mathrm{BBB}$ is essential in controlling $A \beta$ levels in the brain [9]. Enhancing $\mathrm{A} \beta$ clearance across the $\mathrm{BBB}$, as well as protection of the $\mathrm{BBB}$ from injury are among the proposed new strategies for the therapy of $\mathrm{AD}$.

$\mathrm{A} \beta_{1-40}$ and $\mathrm{A} \beta_{1-42}$ peptides, cleaved from amyloid$\beta$ protein precursor by secretases, are the main protein components of neuritic plaques and cerebral amyloid deposits and are considered as important factors in the pathogenesis of Alzheimer's disease [10]. A $\beta$ peptides can form soluble monomers, dimers, oligomers, protofibrils and insoluble fibrils [11]. Amyloid peptides have high affinity for serum amyloid $\mathrm{P}$ component (SAP) that stabilizes the aggregates [12]. Direct infusion of $\mathrm{A} \beta_{1-42}$ into the carotid artery increased the permeability of the BBB to albumin in rats [13]. In Tg2576 mice, an AD model, a higher BBB permeability for albumin was measured in cerebral cortex, which preceded senile plaque formation [14].

Experimental data support the direct toxicity of $\mathrm{A} \beta$ peptides on cultured endothelial cells. Treatments with $\mathrm{A} \beta_{1-40}, \mathrm{~A} \beta_{1-42}$, and $\mathrm{A} \beta_{25-35}$ peptides resulted in decreased viability in cultured peripheral [15], as well as brain endothelial cells $[16,17]$. Monolayer integrity of cerebral endothelial cells is also affected by $\mathrm{A} \beta$ peptides. Increased permeability for paracellular markers induced by $\mathrm{A} \beta_{25-35}$ and $\mathrm{A} \beta_{1-40}$ was detected in rat [18], bovine [19], and human brain microvascular endothelial cells [20].

Few protective molecules against the toxic effect of $\mathrm{A} \beta$ peptides in cerebral endothelial cells were identified so far. In our previous studies we found that pentosan polysulfate (PPS), a semisynthetic highly sul- fated polysaccharide can favorably regulate BBB phenotype [21], and protect against prion peptide [22,23] and lipopolysaccharide-induced toxicity [24] in brain endothelial cells. Although pentosan can inhibit the binding of endogenous glycosaminoglycans to $\mathrm{A} \beta$ and this effect was suggested as a potentially effective therapeutical approach to prevent or slow the amyloidogenesis in $\mathrm{AD}$ [25], pentosan was not tested on brain endothelial cells treated with $\mathrm{A} \beta$ peptides.

The aim of the study was to investigate the effect of pentosan on $\mathrm{A} \beta$ peptide-induced changes in cell viability and $\mathrm{BBB}$ functions in a relevant in vitro $\mathrm{BBB}$ model. Primary rat brain endothelial cells were cocultured with rat glial cells to induce barrier properties. The modulatory effects of serum amyloid $\mathrm{P}$ component (SAP) in BBB dysfunction induced by $\mathrm{A} \beta$ were also studied.

\section{MATERIALS AND METHODS}

All reagents were purchased from Sigma, Hungary, unless otherwise indicated.

\section{Peptides}

Peptides $\mathrm{A} \beta_{1-40}$ and $\mathrm{A} \beta_{1-42}$ were synthesized at the Department of Medical Chemistry, University of Szeged, as it was previously described [26,27]. Prior to measurements the purified peptide was dissolved in 1,1,1,3,3,3-hexafluoro-2-propanol (HFIP; Sigma) and incubated overnight at room temparature in order to destroy the pre-formed aggregates. Aliquots were transferred into Eppendorf tubes and HFIP was evaporated in vacuo. Dried peptide films were stored at $-80^{\circ} \mathrm{C}$ until use. Oligomers were prepared by resuspending the film in phosphate buffered saline (PBS). Oligomerization of the peptide was checked by TEM. Sampling for TEM and image preparation was done by following a standard protocol [28,29]. According to the TEM investigations, samples contained globulomers with a diameter of 5-7 nm either alone or in chain-like or annular assemblies, but not classical protofibrillar aggregates, which are 50-200 nm long (Fig. 1).

\section{Cell culture}

Primary cultures of cerebral endothelial cells were prepared from 2-week-old rats as described earlier in detail [24]. Forebrains were collected in ice cold sterile PBS; meninges were removed, gray matter was minced 


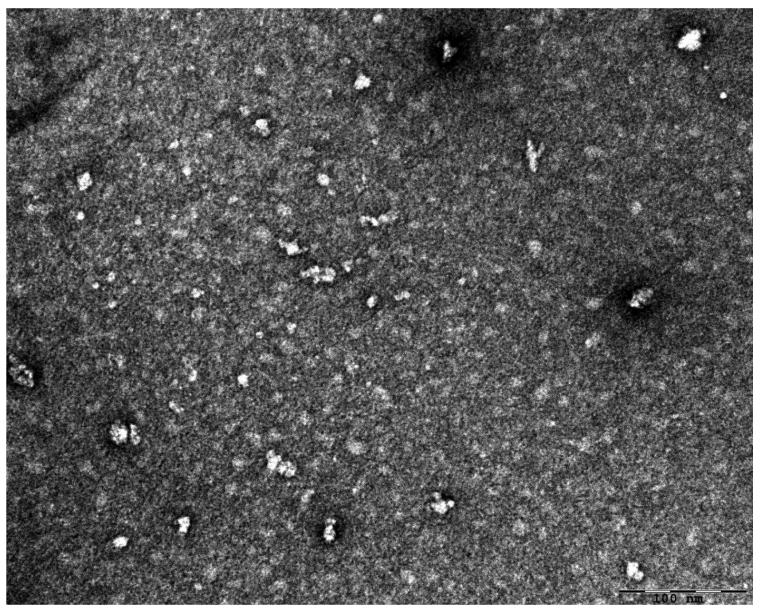

Fig. 1. TEM image of $\mathrm{A} \beta_{1-42}$ peptide dissolved in physiological salt solution to a concentration of $75 \mu \mathrm{M}$, containing a mixture of oligomers and small protofibrillar structures.

by scalpels to $1 \mathrm{~mm}^{3}$ pieces and digested with $1 \mathrm{mg} / \mathrm{ml}$ collagenase CLS2 (Worthington, USA) in Dulbecco's modified Eagle medium (DME) for $1.5 \mathrm{~h}$ at $37^{\circ} \mathrm{C}$. Microvessels were separated by centrifugation in $20 \%$ bovine serum albumin (BSA)-DME $(1000 \times g, 20 \mathrm{~min})$ from myelin containing elements, and further digested with $1 \mathrm{mg} / \mathrm{ml}$ collagenase-dispase (Roche) in DME for $1 \mathrm{~h}$. Microvascular endothelial cell clusters were separated on a $33 \%$ continuous Percoll gradient (1000 $\times g, 10 \mathrm{~min}$ ), collected, and washed twice in DME before plating on collagen type IV and fibronectin coated dishes, multiwell plates (Falcon, Becton Dickinson) or cell culture inserts (Transwell clear, $1 \mathrm{~cm}^{2}$; pore size, $0.4 \mu \mathrm{m}$, Costar). Cultures were maintained in DME supplemented with $5 \mu \mathrm{g} / \mathrm{ml}$ gentamicin, $20 \%$ plasmaderived bovine serum (First Link, UK), $1 \mathrm{ng} / \mathrm{ml}$ basic fibroblast growth factor (Roche) and $100 \mu \mathrm{g} / \mathrm{ml}$ heparin. In the first 2 days, culture medium contained puromycin (4 $\mu \mathrm{g} / \mathrm{ml}$ ) to selectively remove P-glycoprotein negative contaminating cells [30].

Cultures reached confluency within a week and were used for experiments. To induce BBB characteristics, brain endothelial cells were treated with gliaconditioned medium or co-cultured with rat cerebral glial cells $[18,24]$. Primary cultures of glial cells were prepared from newborn Wistar rats. Meninges were removed, and cortical pieces were mechanically dissociated in DME containing $5 \mu \mathrm{g} / \mathrm{ml}$ gentamicin and $10 \%$ fetal bovine serum and plated in poly-L-lysin coated 12-well dishes and kept for minimum 3 weeks before use. In confluent glia cultures $90 \%$ of cells were immunopositive for the astroglia cell marker glial fibril- lary acidic protein, while the remaining $10 \%$ was immunopositive for CD11b, a marker of microglia. For co-culture brain endothelial cells in cell culture inserts were placed into multiwells containing astroglia at the bottom of the wells with endothelial culture medium in both compartments. When brain endothelial cells became almost confluent $550 \mathrm{nM}$ hydrocortisone was added to the culture medium [18]. Before experiments the cells were treated with CPT-cAMP $(250 \mu \mathrm{M})$ and RO 201724 (17.5 $\mu \mathrm{M}$; Roche) for $24 \mathrm{~h}$ to tighten junctions and elevate resistance $[18,30]$.

\section{Treatments}

In case of viability assays the cells were treated with glia-conditioned medium, whereas for all other studies where the culture insert system made it possible coculture was done before treatments. Glia-conditioned medium or glial cells were not present during peptide treatments and experiments.

Peptides were tested at $0-200 \mu \mathrm{g} / \mathrm{ml}$ concentration for $0-48 \mathrm{~h}$ treatment period in brain endothelial cells. The doses of PPS (Cartrophen, Biopharm Australia Pty Ltd.) varied between 1 and $100 \mu \mathrm{g} / \mathrm{ml}$, as described in previous studies $[21,23,24]$. The concentration of human SAP (Merck, Germany) was $40 \mu \mathrm{g} / \mathrm{ml}$. In cell viability experiments done in 96-well format, where the abluminal surface was not available the cultures were treated only luminally. In all other experiments where endothelial cells were cultured on the membrane of the inserts $\mathrm{A} \beta_{1-42}$ was added both luminally and abluminally. Incubations of brain endothelial cells with the peptides were performed in endothelial culture medium.

\section{Electron microscopy}

Cells grown on the membrane were fixed with $3 \%$ paraformaldehyde in cacodylate buffer $(\mathrm{pH}$ 7.5) for $30 \mathrm{~min}$ at $4^{\circ} \mathrm{C}$. After washing with cacodylate buffer several times, the membranes of the culture inserts with the cells on the two sides were removed from their support and placed into 24-well chamber slide and were postfixed in $1 \% \mathrm{OsO}_{4}$ for $30 \mathrm{~min}$. Following washing with distilled water, the cells on the membrane were dehydrated in graded ethanol, block-stained with $2 \%$ uranyl acetate in $70 \%$ ethanol for $1 \mathrm{~h}$ and embedded in Taab 812 (Taab; Aldermaston, Berks, UK). Ultrathin sections were cut perpendicularly for the membrane using a Leica UCT ultramicrotome (Leica Microsystems, Milton Keynes, UK) and examined using a Hi- 
tachi 7100 transmission electron microscope (Hitachi Ltd., Tokyo, Japan). Electron micrographs were made by Megaview II (lower resolution, Soft Imaging System, Munster, Germany). Brightness and contrast were adjusted if necessary using Adobe Photoshop CS3 (San Jose, CA, USA).

\section{Cell cytotoxicity assays}

Living cells convert the yellow dye 3-(4,5-dimethyltiazol-2-yl)-2,5-diphenyltetrazolium bromide (MTT, Sigma M5655) to purple, insoluble formazan crystals. For MTT reduction assay the rat brain endothelial cells were cultured in 96 well plates. After treatments the cells were incubated with $0.5 \mathrm{mg} / \mathrm{ml}$ MTT solution for $3 \mathrm{~h}$ in $\mathrm{CO}_{2}$ incubator. The amount of formazan crystals was dissolved in dimethyl-sulfoxide and determined by measuring absorbance at $570 \mathrm{~nm}$ with microplate reader (Multiskan Ascent, Thermo Electron Corp., MA, USA).

To determine lactate dehydrogenase (LDH) from culture supernatant a commercially available kit (Cytotoxicity detection kit LDH, Roche) was used. For LDH release assay rat brain endothelial cells were cultured in 96 well plates. After treatments $50 \mu \mathrm{l}$ samples from culture supernatants were incubated with equal amounts of reaction mixture for $15 \mathrm{~min}$. The enzymic reaction was stopped by $0.1 \mathrm{M} \mathrm{HCl}$. Absorbance was measured at a wavelength of $492 \mathrm{~nm}$ with a microplate reader (Multiskan Ascent, Thermo Electron Corp., MA, USA). Cytotoxicity is calculated as percentage of the total $\mathrm{LDH}$ release from cells treated by $1 \%$ Triton X-100 detergent.

\section{Evaluation of the barrier integrity}

Transendothelial electrical resistance (TEER), representing the permeability of tight junctions for sodium ions, was measured by an EVOM resistance meter (World Precision Instruments Inc., USA) using STX-2 electrodes, and it was expressed relative to the surface area of endothelial monolayer $\left(\Omega \times \mathrm{cm}^{2}\right)$. TEER values of cell-free inserts $\left(90-100 \Omega \times \mathrm{cm}^{2}\right)$ were subtracted from the measured data. The TEER of rat primary brain endothelial monolayers in co-culture varied between 250 and $700 \Omega \times \mathrm{cm}^{2}$, with an average of $358 \pm$ $41 \Omega \times \mathrm{cm}^{2}$, (mean \pm S.D., $n=84$, experiments from 6 separate isolations).

The flux of sodium fluorescein and Evans bluelabeled albumin across endothelial monolayers was determined as previously described [24,31]. Cell cul- ture inserts, following treatment and measurement of TEER, were transferred to 12 -well plates containing $1.5 \mathrm{ml}$ Ringer-Hepes solution (118 mM NaCl, $4.8 \mathrm{mM}$ $\mathrm{KCl}, 2.5 \mathrm{mM} \mathrm{CaCl}_{2}, 1.2 \mathrm{mM} \mathrm{MgSO} 4,5.5 \mathrm{mM}$ Dglucose, $20 \mathrm{mM}$ Hepes, $\mathrm{pH}$ 7.4) in the basolateral compartments. In apical chambers culture medium was replaced by $500 \mu$ l Ringer-Hepes containing $10 \mu \mathrm{g} / \mathrm{ml}$ sodium fluorescein (mw: $376 \mathrm{Da}$ ) and $165 \mu \mathrm{g} / \mathrm{ml}$ Evans blue bound to $0.1 \%$ BSA (mw: $67 \mathrm{kDa}$ ). The inserts were transferred at 20,40, and $60 \mathrm{~min}$ to a new well containing Ringer-Hepes solution. The concentrations of the marker molecules in samples from the upper and lower compartments were determined. Evans blue concentration was measured by a Labsystems Multiskan plate reader (absorbency: $620 \mathrm{~nm}$ ), and fluorescein levels by a Polarstar Galaxy fluorescent plate reader (BMG Labtechnologies; emission: $525 \mathrm{~nm}$, excitation: $440 \mathrm{~nm}$ ). Flux across cell-free inserts was also measured.

Transport was expressed as $\mu \mathrm{l}$ of donor (luminal) compartment volume from which the tracer is completely cleared. Transendothelial permeability coefficient $\left(\mathrm{P}_{e}\right)$ was calculated as previously described [18, 24]. Cleared volume was calculated from the concentration $(\mathrm{C})$ of the tracer in the abluminal and luminal compartments and the volume (V) of the abluminal compartment $(0.5 \mathrm{ml})$ by the following equation:

$$
\text { Cleared volume }(\mu l)=\frac{C_{\text {abluminal }} \times V_{\text {abluminal }}}{C_{\text {luminal }}}
$$

The average cleared volume was plotted $v s$. time, and permeability $\times$ surface area product value for endothelial monolayer $\left(\mathrm{PS}_{e}\right)$ was calculated by the following formula:

$$
\frac{1}{P S_{\text {endothelial }}}=\frac{1}{P S_{\text {total }}}-\frac{1}{P S_{\text {insert }}}
$$

$\mathrm{PS}_{e}$ divided by the surface area $\left(1 \mathrm{~cm}^{2}\right.$ for Transwell12) generated the endothelial permability coefficient $\left(\mathrm{P}_{e} ;\right.$ in $\left.10^{-3} \mathrm{~cm} / \mathrm{min}\right)$.

\section{Immunohistochemistry}

Brain endothelial cell monolayers cultured on fibronectin- and collagen-coated glass coverslips and treated with $\mathrm{A} \beta$ peptides and/or PPS were stained for ZO-1, occludin and claudin-5 junctional proteins. The cultures were washed in PBS and fixed with ethanol (95 vol.\%)-acetic acid (5 vol.\%) for $10 \mathrm{~min}$ at $-20^{\circ} \mathrm{C}$ (ZO-1), with ethanol for $30 \mathrm{~min}$ at $4^{\circ} \mathrm{C}$ (claudin-5) with $4 \%$ paraformaldehyde for $30 \mathrm{~min}$ at $4^{\circ} \mathrm{C}$ (occludin). Cells were blocked with $3 \%$ BSA and incubat- 
ed with primary antibodies anti-ZO-1 (Zymed, USA), anti-claudin-5 (Zymed, USA), anti-occludin (Zymed, USA), for $1 \mathrm{~h} 30 \mathrm{~min}$. Incubation with secondary antibody Cy3-labelled anti-rabbit IgG (Sigma, Hungary) lasted for $1 \mathrm{~h}$. Between incubations cells were washed three times with PBS. Coverslips were mounted in Gel Mount (Biomeda, USA) and staining was examined by a NikonEclipse TE2000 fluorescent microscope (Nikon, Japan) and photographed by a Spot RT digital camera (Diagnostic Instruments, USA).

\section{Preparation of laser-grated surfaces and atomic force microscopy}

Master grating based two-beam interference (TBI) arrangement was applied to generate sub-micrometer periodic intensity modulation in the beam irradiating the samples [32]. The fourth harmonic of a Nd:YAG laser $(\mathrm{lFH}=266 \mathrm{~nm}, t=10 \mathrm{~ns}, f=10 \mathrm{~Hz})$ impinged on a diffraction grating (PUV 1200, Spectrogon), and the first order diffracted beams were recombined at the sample plane, after propagation trough a fused silica block. The samples were NBK7 substrates evaporated by gold - silver bimetallic layers, and spin-coated by polycarbonate. Samples were treated by s-polarized beams, to produce linear gratings as described earlier [32]. The laser treated surfaces were investigated by atomic force microscopy (AFM) operating in digital pulsed force mode (DPFM, Witec GmbH, Germany). The advantage of this scanning mode is the possibility to map the micromechanical properties of the surface with high resolution. We applied standard PFM tips (NSC 18/NoA1, $2.5 \mathrm{~N} / \mathrm{m}$ ) and collected pictures about the topography and adhesion. The purpose of these measurements was to compare the adhesion distribution on structures produced by different laser-treatment methods.

To examine biomolecules the samples with lasergrated surfaces were completely immersed in fresh PBS solutions containing $\mathrm{A} \beta_{1-42}$ peptide at a concentration of $10 \mu \mathrm{g} / \mathrm{ml}(2.2 \mu \mathrm{M})$, with or without PPS at a concentration of $100 \mu \mathrm{g} / \mathrm{ml}$. This dose of $\mathrm{A} \beta_{1-42}$ was determined in a preliminary experiment to optimize the peptide amount for AFM measurement and particle counting. Incubation of the samples in the solutions lasted for $1 \mathrm{~h}$ at $37^{\circ} \mathrm{C}$, then all samples were washed three times in sterile distilled water on a horizontal shaker and finally allowed to dry overnight at room temperature. A PSIA AFM operating in tapping-mode was applied to detect the attached biomolecules using NTMDT tips (NSG11, 5.5 N/m, $150 \mathrm{kHz}$ ). The AFM pic- tures were analyzed by Spot Advance software (Diagnostic Instruments Inc., Sterling Heights, MI, USA) to obtain the number and size of the attached biomolecule particles on the laser-grated surface of the samples. Particles were counted on 25 fields of $1 \mu \mathrm{m}^{2}$ size from 3 different samples from each treatment groups from 2 separate experiments.

\section{Statistical analysis}

All data presented in Results section are means \pm S.E.M. The values were compared using the analysis of variance followed by Dunnett, Bonferroni or NewmanKeuls posthoc tests using GraphPad Prism 5.0 software. Changes were considered statistically significant at $p<0.05$. All experiments were repeated at least three times, the number of parallel wells or inserts for each treatment and time point varied between 3 and 8 .

\section{RESULTS}

The effect of A $\beta$ peptide fragments on the morphology of rat brain endothelial cells

In physiological solutions the $\mathrm{A} \beta_{1-42}$ peptide can easily aggregate into oligomers, protofibrils and fibrils. The size distribution of the aggregates is highly dependent on the experimental conditions. In our experiments the amyloid peptides were applied in oligomeric form, as it is represented in Fig. 1. Under the circumstances we applied, A $\beta_{1-42}$ formed globular specii (5$7 \mathrm{~nm}$ ), which were arranged occassionally into annular or beaded chain-like assemblies with a maximum size of 15-20 nm. In the course of $\mathrm{A} \beta_{1-42}$ treatment, the oligomers were diluted directly to the cell culture medium to the required concentration. In the solution phase, these oligomers are assumed to remain stable for an elongated time, as their molecular environment is very similar to that of the so-called 'Amyloid Derived Diffusible Ligands' (ADDLs), which possessed the same structural characteristics, i.e., globular oligomers in cell culture medium and kept their stability in the course of the biological experiments [33]. In-depth examination of the ADDL population revealed, that it contains fairly stable subpopulations of amyloid oligomers of different size [34]. Therefore, upon application of such preparations, one has to consider that the observed effect was exerted by a heterogeneous oligomeric population.

Furthermore, the amyloid aggregates can be accumulated on the membrane surfaces, as it was observed 

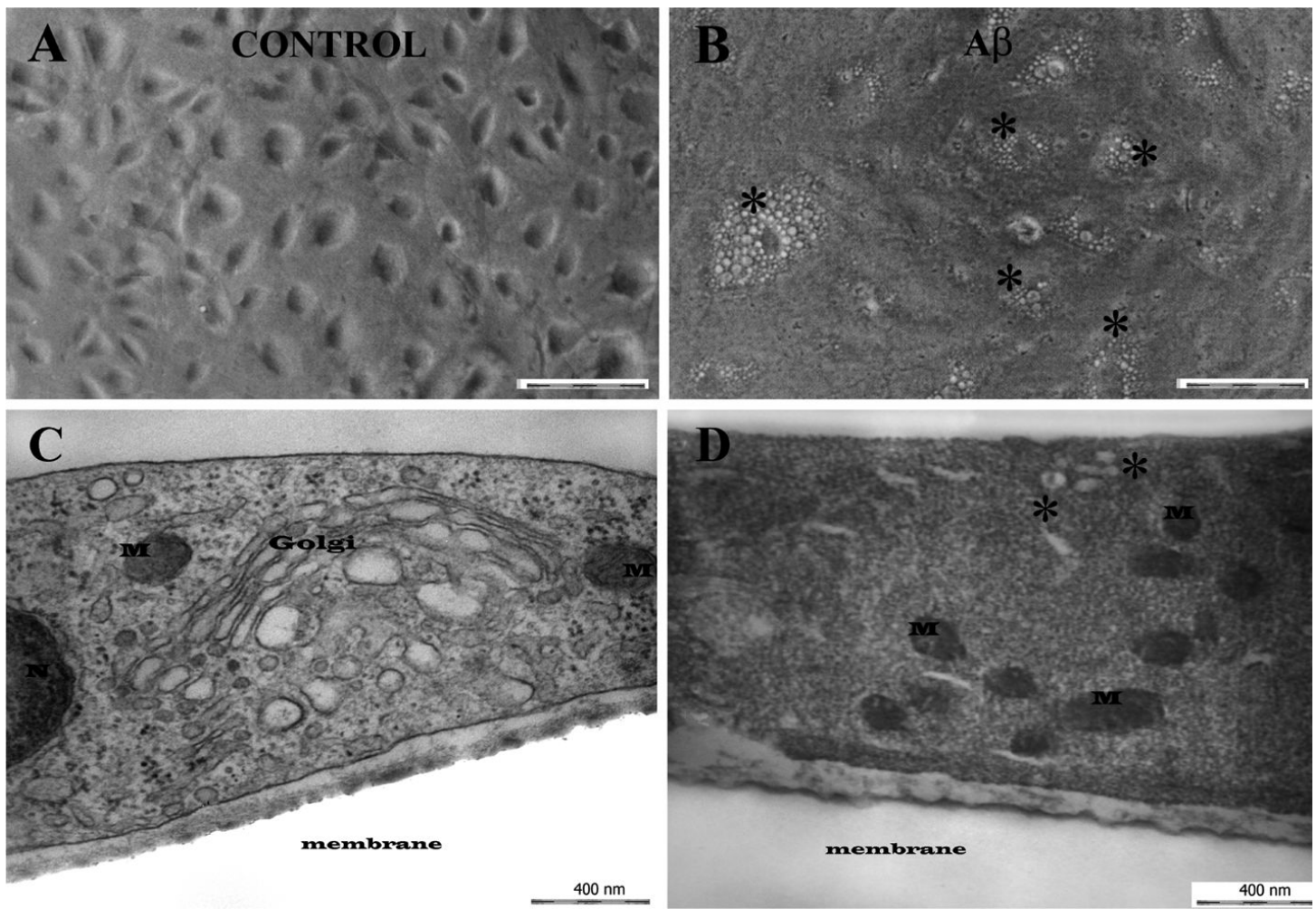

Fig. 2. The effect of $\mathrm{A} \beta$ peptide fragments on the morphology of rat brain endothelial cells. Phase contrast (A-B) and transmission electron microscopy (C-D) images of brain endothelial cells grown on the filter membrane of Transwell inserts. Typical details of control (A,C) and A $\beta$ 1-42 peptide treated (B,D) endothelial cells. Bar for phase contrast microscopy (A-B): $100 \mu \mathrm{m}$; Bar for electron microscopy (C-D): $400 \mathrm{~nm}$. Asterisks show cytoplasmic vacuoles. N: nucleus, M: mitochondria.

in our experiments as well. Large assemblies of the oligomers were found to adhere to the surface of the endothelial cells from the culture medium therefore the shape of cells could hardly be seen in light microscopy (Fig. 2B). A remarkable vacualisation could be observed around the nucleus in the cell cytoplasm induced by the peptide treatment (Fig. 2B). In the cytoplasm of control cells every cell organelle is bordered by clearly visibly membrane (Fig. 2C). In control cells well-developed Golgi, mitochondria, a small part of the nucleus, and small dots of ribosomes are visible (Fig. 2C), while the cytoplasm of the $\mathrm{A} \beta$-treated endothelial cell is more dense than the control one and several mitochondria can be seen (Fig. 2D). The structure of mitochondria in $\mathrm{A} \beta$ peptide-treated cells shows less space between the outer and inner membranes but there is some separation from the cytoplasm. In $\mathrm{A} \beta_{1-42^{-}}$ treated cells less, if any, well preserved Golgi, more vacuoles and organelles unidentifiable by morphology were found compared with the control ones.

In control conditions endothelial cells show smooth oval nuclei with uneven distribution of chromatin sub- stance and several caveolae and caveolae-like invaginations on the luminal side (Fig. 3A). Ribosomes are clearly visible. The shape of nuclei of the $\mathrm{A} \beta_{1-42}$ peptide-treated endothelial cells are less regular, the chromatin substance is more uniform. No caveolaelike invaginations but vacuoles can be observed. The cytoplasm is dense and ribosomes are indistinguishable (Fig. 3C). In untreated cells elaborate intercellular junctions could be seen. A long overlapping part of two endothelial cell processes is shown on Fig. 4A, "kissing points" are indicated by arrows. The dense material at the kissing points demonstrates tight intercellular junctions. In contrast, the connection between two $\mathrm{A} \beta_{1-42}$-treated endothelial cells (Fig. 4C) is not tight, the processes do not lie on each other but one process is circled by the other one. Pale kissing points (arrows) can be observed. The process on the left hand side is full with vacuoles. Although some regular tight junctions (TJs) can be found in the $\mathrm{A} \beta_{1-42}$-treated cells too, the irregular contacts, junctions with less kissing points were more typical. Vacuolisation of processes and cell bodies and decreased number of caveolae were 

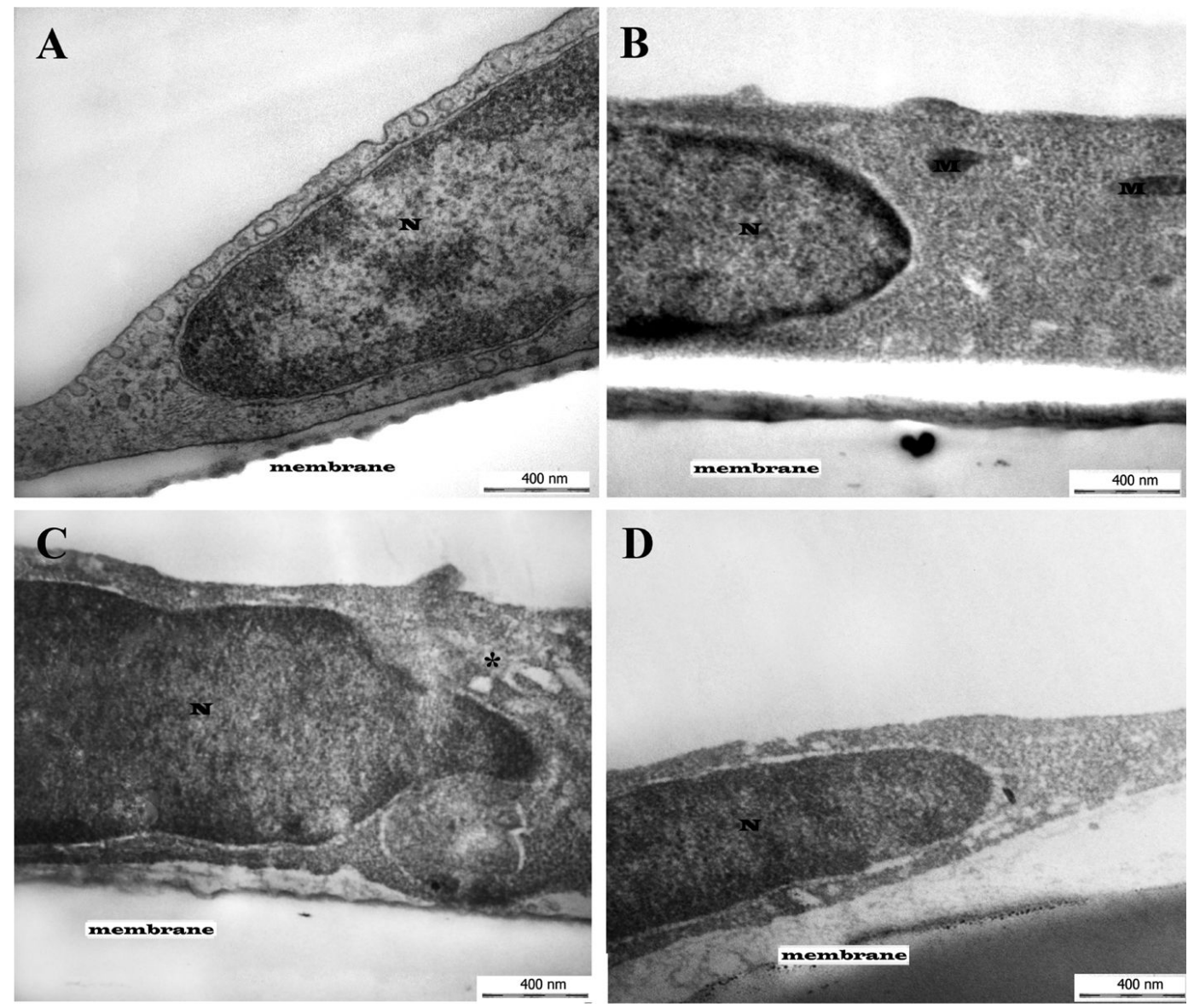

Fig. 3. The effect of $\mathrm{A} \beta$ peptide fragments on the morphology of rat brain endothelial cells by transmission electron microscopy. Brain endothelial cells were grown on filter membranes of Transwell inserts. Typical details of control (A), pentosan (B), A $\beta_{1-42}$ peptide (C), A $\beta_{1-42}$ and pentosan (D) treated endothelial cells. Bar for electron microscopy: $400 \mathrm{~nm}$. Asterisks show cytoplasmic vacuoles. N: nucleus, M: mitochondria.

common (shown by asterisks on Figs 2-4). PPS treatment did not change the morphology of brain endothelial cells as compared to control (Figs 3B and 4B) and could ameliorate the ultrastructural changes induced by $\mathrm{A} \beta_{1-42}$ (Figs 3D and 4D).

\section{The effect of $A \beta$ peptide fragments on rat brain endothelial cells: toxicity assays}

The direct effect of $\mathrm{A} \beta$ peptid fragments on brain endothelial cell viability was examined in two toxicity assays. The yellow MTT dye was efficiently converted to purple formazan crystals by non-treated and scrambled peptide treated endothelial cells as demonstrated by the high absorbance values (Fig. 5A). A $\beta_{1-42}$ peptide-treatment in concentrations higher than $10 \mu \mathrm{M}$ for $48 \mathrm{~h}$ significantly decreased the MTT reduction. A similar effect was seen for $\mathrm{A} \beta_{1-40}$ peptide at $50 \mu \mathrm{M}$ dose. In the LDH release assay the $100 \mu \mathrm{M}$ and 200 $\mu \mathrm{M}$ concentrations of $\mathrm{A} \beta_{1-42}$ peptide produced significant enzyme leakage from the brain endothelial cells indicating membrane damage (Fig. 5B). The calculated cytotoxicity based on $\mathrm{LDH}$ release was $9.2 \%$ at $100 \mu \mathrm{M}$ and $19.5 \%$ at $200 \mu \mathrm{M} \mathrm{A} \beta_{1-42}$ peptide concentrations. Lower doses of $\mathrm{A} \beta_{1-40}$ and $\mathrm{A} \beta_{1-42}$ peptides did not exert toxic effect on brain endothelial cells in this test.

Modulating effect of SAP on A $\beta_{1-42}$ peptide-induced changes in endothelial barrier integrity

In preliminary functional studies $25 \mu \mathrm{M} \mathrm{A} \beta_{1-42}$ was found to be optimal to reproducibly induce damage to BBB integrity and to examine protective effects. The selected $25 \mu \mathrm{M}$ dose of $\mathrm{A} \beta$ for the permeability experiments is in good agreement with the treatment doses of $\mathrm{A} \beta$ for brain endothelial cells in the literature [15, $16,35,36]$. 

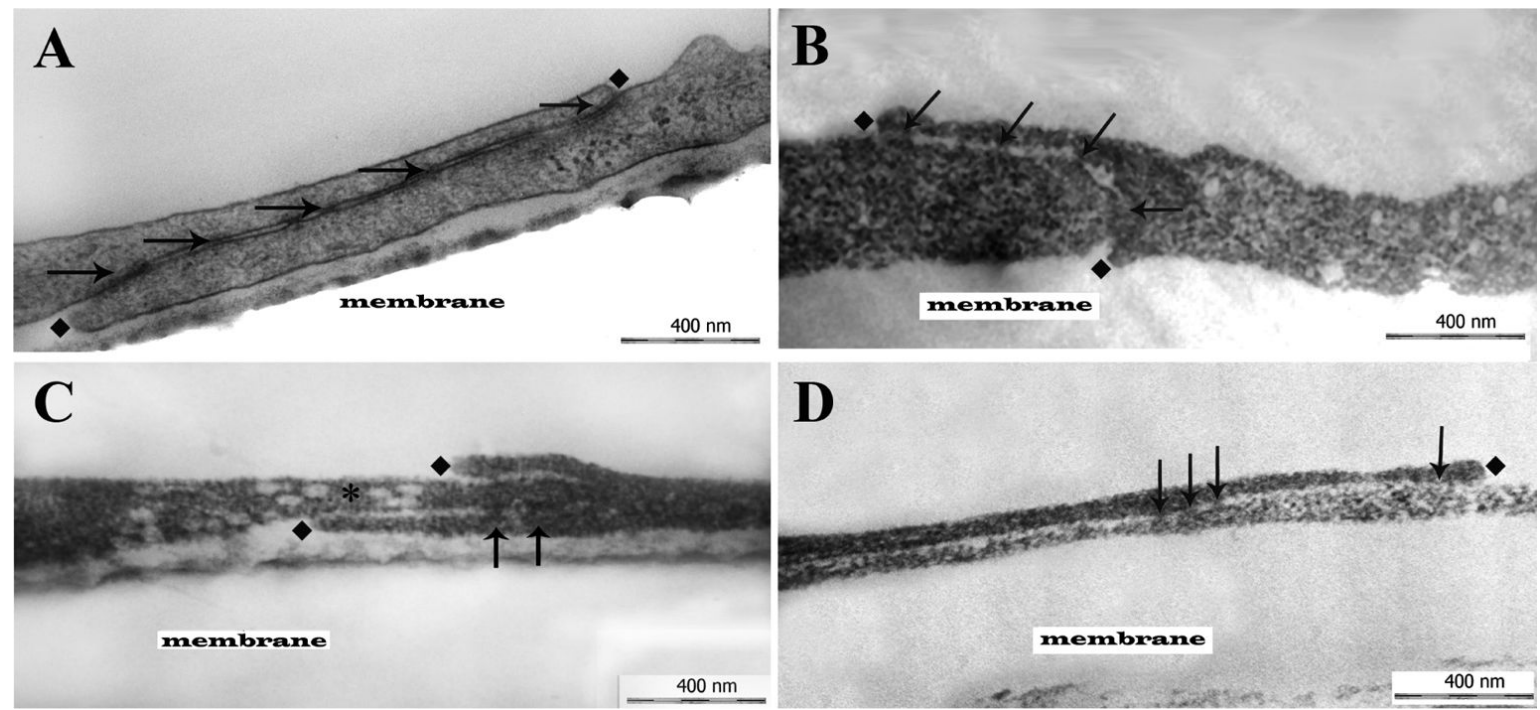

Fig. 4. The effect of $\mathrm{A} \beta$ peptide fragments on the morphology of intercellular junctions of rat brain endothelial cells by transmission electron microscopy. Brain endothelial cells were grown on filter membranes of Transwell inserts. Typical details of control (A), pentosan (B), A $\beta_{1-42}$ peptide (C), $\mathrm{A} \beta_{1-42}$ and pentosan (D) treated endothelial cells. Bar for electron microscopy: $400 \mathrm{~nm}$. The squares indicate the starting and the ending point, arrows the kissing points of the interendothelial junctions. Asterisks show cytoplasmic vacuoles.
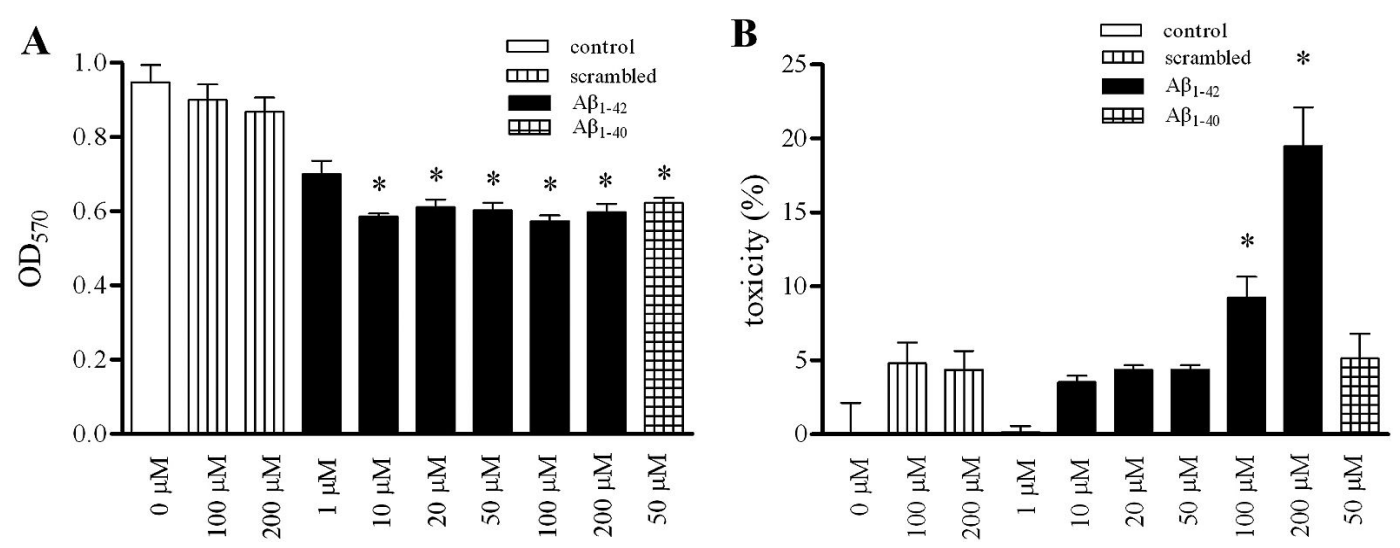

Fig. 5. The effect of $\mathrm{A} \beta$ peptide fragments on rat brain endothelial cells after $48 \mathrm{~h}$ treatment in MTT reduction assay (A) and LDH release assay (B). All values presented are means \pm S.E.M., $n=8, p<0.05$.

Treatment of monolayers with $\mathrm{A} \beta_{1-42}$ reduced the TEER significantly after $24 \mathrm{~h}$ and the values further decreased at the $48 \mathrm{~h}$ timepoint (Fig. 6A). In A $\beta_{1-42}$ peptide treated monolayers the flux of fluorescein increased as compared to the control (Fig. 6B). The $\mathrm{P}_{e}$ values for permeability marker albumin were lower with one order of magnitude than the values for fluorescein, a paracellular marker, in agreement with literature data $[18,37]$ and our previous results [24,31]. The permeability for albumin was also significantly elevated in monolayers treated with $\mathrm{A} \beta_{1-42}$ (Fig. 6C).

When $\mathrm{A} \beta_{1-42}$ was co-administered with physiological concentration of SAP ( $40 \mu \mathrm{g} / \mathrm{ml})$ significantly re- duced TEER values were measured at $24 \mathrm{~h}$ and $48 \mathrm{~h}$ timepoints as compared to control or $\mathrm{A} \beta_{1-42}$ peptidetreated monolayers (Fig. 6A). The $\mathrm{A} \beta_{1-42}$ peptideinduced elevations in both fluorescein (Fig. 6B) and albumin (Fig. 6C) permeability were siginificantly further increased by the presence of SAP. SAP treatment alone had no effect on the resistance or permeability of the endothelial monolayers (Fig. 6).

The effect of PPS on $A \beta_{1-42}$ peptide-induced changes in rat brain endothelial cell morphology and function

In the viability assays pentosan could only slightly inhibit the $\mathrm{A} \beta_{1-42}$ peptide-induced decrease in MTT 

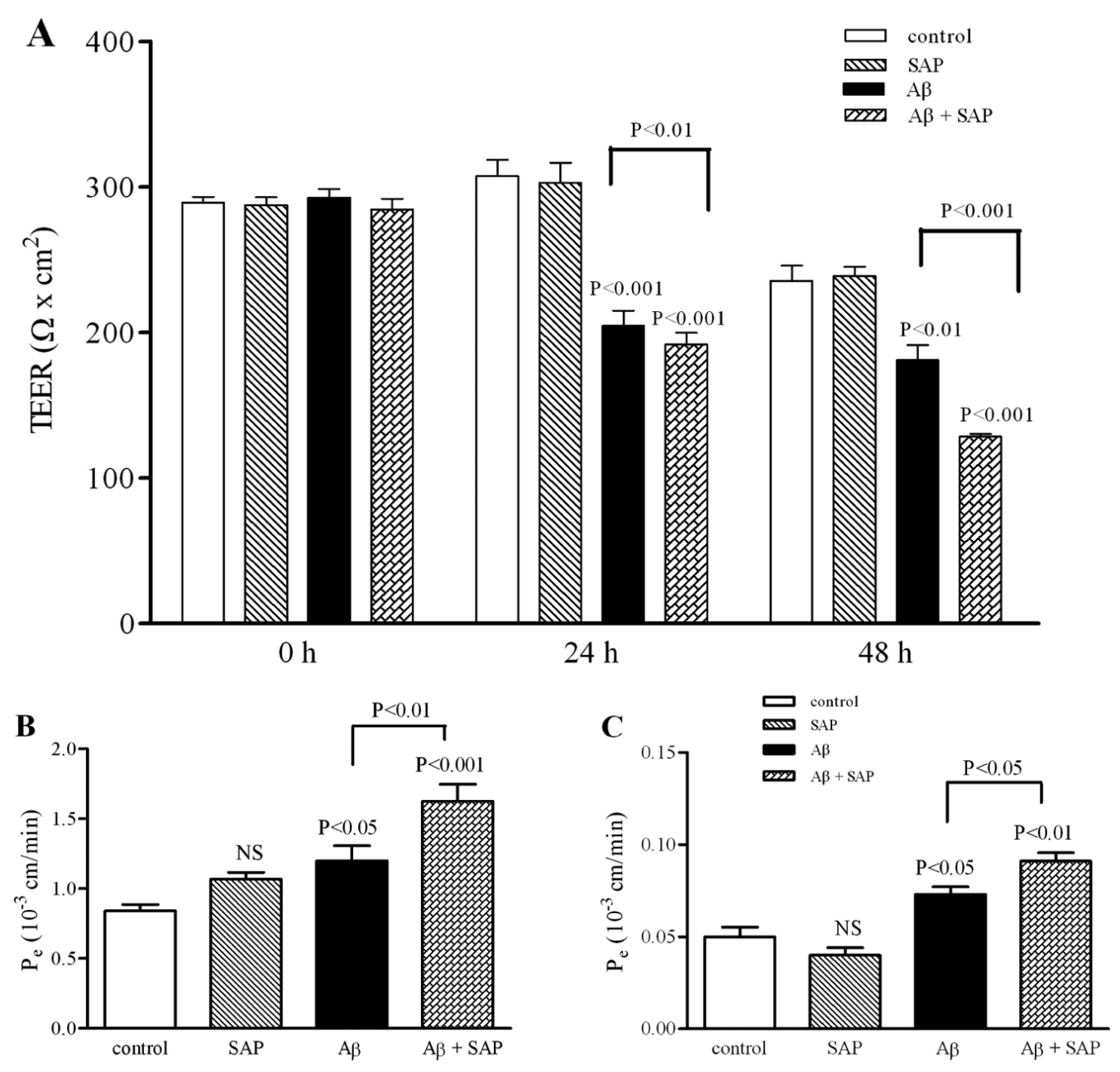

Fig. 6. Changes in transendothelial electrical resistance (TEER) (A), and in transendothelial permeability $\left(\mathrm{P}_{e}\right)$ for permeability markers sodium fluorescein (B) and Evans blue labelled albumin (C) in rat brain endothelial cell monolayers treated with $\mathrm{A} \beta_{1-42}$ peptide $(25 \mu \mathrm{M})$ and serum amyloid P component (SAP, $40 \mu \mathrm{g} / \mathrm{ml}$ ). All values presented are means \pm S.E.M., $n=8, p<0.05$.

reduction at the highest, $100 \mu \mathrm{g} / \mathrm{ml}$ dose (Fig. 7A). Lower concentrations of PPS $(0.1-10 \mu \mathrm{g} / \mathrm{ml})$ had no effect. Pentosan alone did not change MTT reduction in the cells not even at high concentrations. PPS at 100 $\mu \mathrm{g} / \mathrm{ml}$ dose could effectively block the LDH release after amyloid exposure (Fig. 7B).

The same dose of PPS effective in the toxicity assays had protective effect against the $\mathrm{A} \beta_{1-42}$ peptideinduced TEER decrease in brain endothelial cells at $24 \mathrm{~h}$ and $48 \mathrm{~h}$ timepoints (Fig. 8A). Pentosan alone had no significant effect on barrier integrity. The $\mathrm{A} \beta_{1-42}$ treatment-induced increases in the BBB permeability for markers (Figs 8B and 8C) were significantly decreased by PPS, however PPS alone did not change the permeability of monolayers.
Effect of $A \beta_{1-42}$ peptide on immunostaining for junctional proteins in rat brain endothelial cells

To further investigate the effect of $\mathrm{A} \beta_{1-42}$ on the morphology of interendothelial junctions of the brain endothelial cells immunostainings for junctional proteins were also performed. In control monolayers ZO1 , occludin and claudin-5 staining localized to the cell border and the tightly apposed, elongated endothelial cells were well delineated (Fig. 9). The pattern of the staining has been dramatically changed in $\mathrm{A} \beta_{1-42^{-}}$ treated $(25 \mu \mathrm{M}, 48 \mathrm{~h})$ cells. Treatment with $\mathrm{A} \beta$ peptide resulted in decreased immunostaining intensity, fragmentation or loss of the continuous cortical staining pattern, and appearance of intercellular gaps in rat brain endothelial cells (shown by arrows on Fig. 9). 

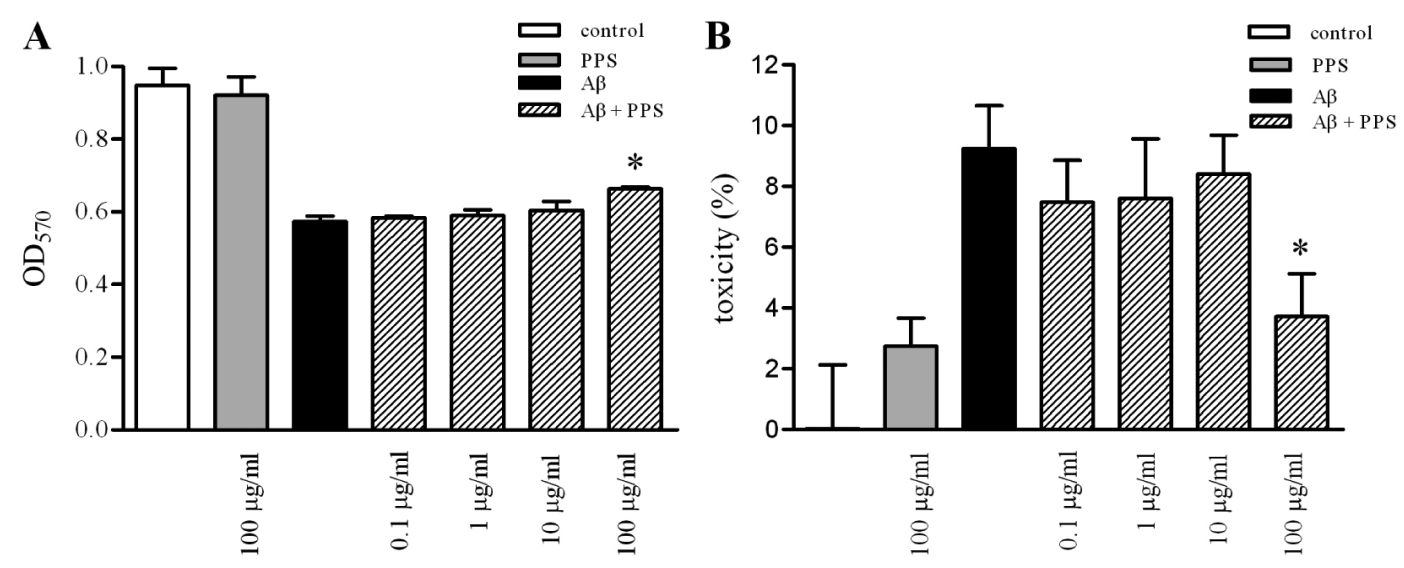

Fig. 7. The effect of PPS on rat brain endothelial cells induced toxicity of $\mathrm{A} \beta_{1-42}$ peptide in MTT reduction assay (A) and LDH release assay (B). All values presented are means \pm S.E.M., $n=8, p<0.05$.

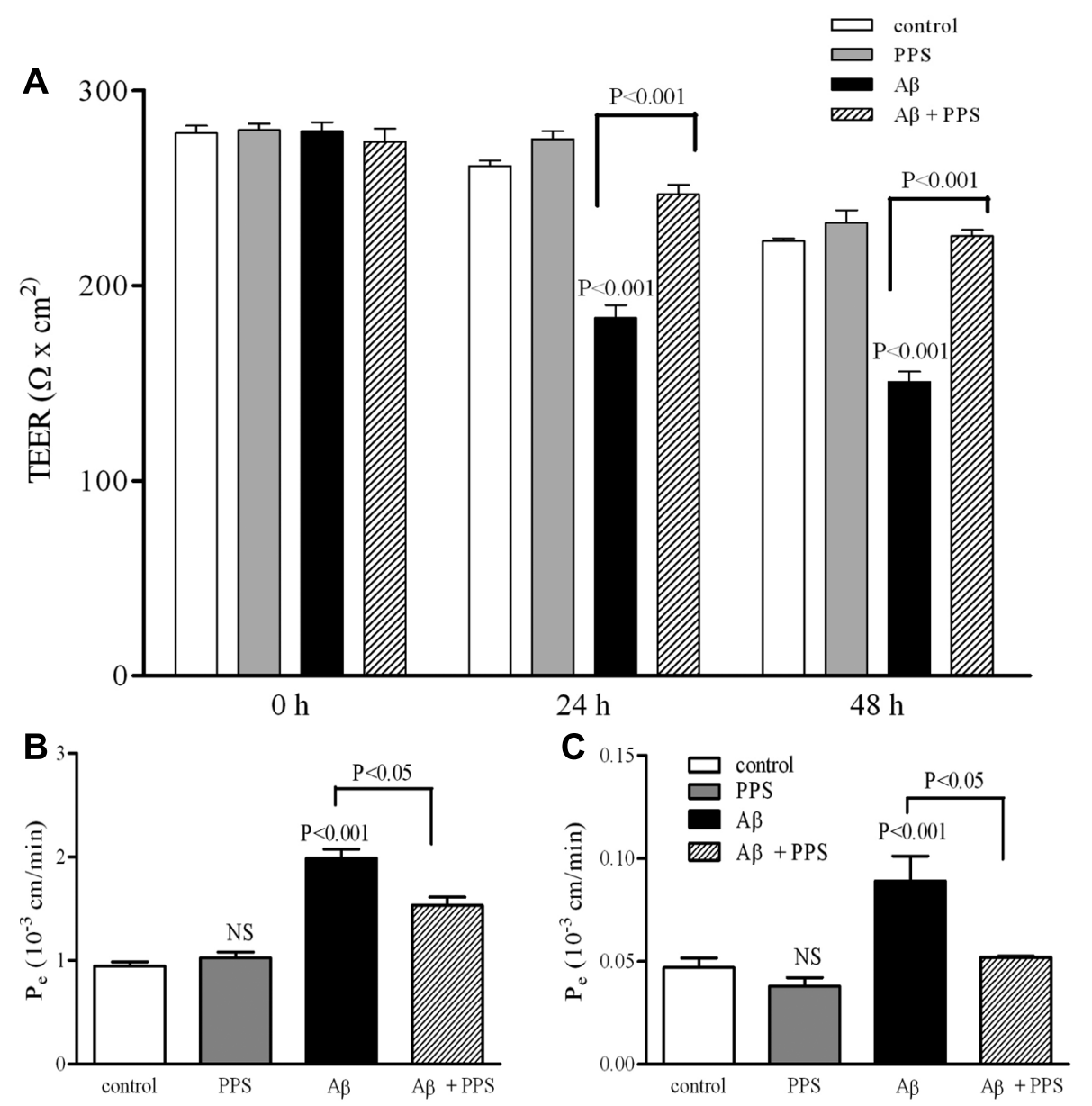

Fig. 8. Changes in transendothelial eletrical resistance (TEER) (A), and in transendothelial permeability $\left(\mathrm{P}_{e}\right)$ for permeability markers sodium fluorescein (B) and Evans blue labelled albumin (C) in rat brain endothelial cell monolayers treated with $\mathrm{A} \beta_{1-42}$ peptide $(25 \mu \mathrm{M})$ and pentosan polysulfate (PPS, $100 \mu \mathrm{g} / \mathrm{ml}$ ) for 24 or $48 \mathrm{~h}$. All values presented are means \pm S.E.M., $n=4, p<0.05$. 


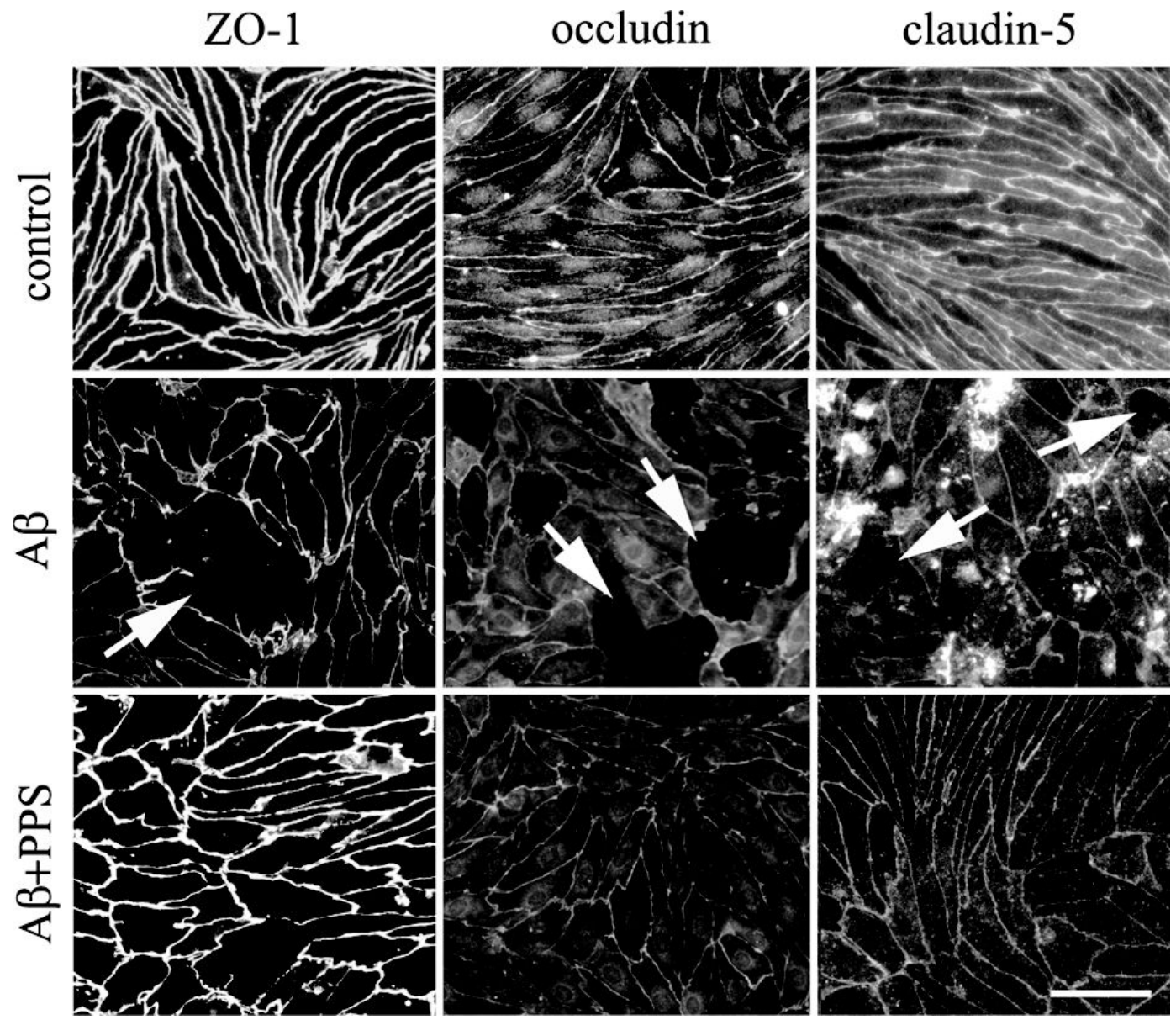

Fig. 9. Effect of $\mathrm{A} \beta_{1-42}$ peptide ( $\left.25 \mu \mathrm{M}\right)$ and pentosan polysulfate (PPS, $100 \mu \mathrm{g} / \mathrm{ml}$ ) for $48 \mathrm{~h}$ on immunostaining for junctional proteins ZO-1, occludin, and claudin-5 in rat brain endothelial cells. Arrows show holes formed between endothelial cells, fragmentation or loss of junctional immunostaining. Bar: $25 \mu \mathrm{m}$.

Co-administration of PPS inhibited these changes, the monolayer integrity was better preserved and the immunostaining pattern resembled to the control ones. The visualization of $\mathrm{A} \beta_{1-42}$ peptide aggregates attached to the cells as cloudy patches by the anti-claudin5 antibody (Fig. 9) is most probably due to non-specific binding of the antibody to the aggregates.

\section{Atomic force microscopy measurement}

To investigate the interaction between $\mathrm{A} \beta_{1-42}$ peptide and pentosan, the biomolecules were attached to linear-grated laser-sculpted surfaces and examined by tapping-mode AFM to reveal the topography (not shown) and adhesion (Fig. 10A). The AFM pictures of the samples demonstrate that $\mathrm{A} \beta_{1-42}$ peptide aggregates attached to the surface quite evenly, with a high density and had an average diameter less than
$33 \mathrm{~nm}\left(100.30 \pm 6.59\right.$ particles $/ \mu \mathrm{m}^{2}$ for aggregates with largest diameter below $33 \mathrm{~nm}$, and $17.44 \pm 1.02$ particles $/ \mu \mathrm{m}^{2}$ for aggregates with largest diameter between 33 and $66 \mathrm{~nm}$; Fig. 10B). PPS molecules gave a small number of very characteristical large, oval aggregates on the samples with a largest diameter of 200-320 nm and attached to the "hills" of the gratings (Fig. 10A). The majority of PPS particles was in the size range of 260-290 nm. There was no overlap between the size distribution of PPS as compared to $\mathrm{A} \beta$ particles from $\mathrm{A} \beta$ or $\mathrm{A} \beta+\mathrm{PPS}$ treatment groups. The AFM investigation has shown that the number of the $\mathrm{A} \beta_{1-42}$ aggregates in the presence of PPS was significantly reduced and the size of attached peptide aggregates became larger ( 0 particle $/ \mu \mathrm{m}^{2}$ for aggregates below 33 $\mathrm{nm} ; 1.42 \pm 0.44$ particles $/ \mu \mathrm{m}^{2}$ for $33-66 \mathrm{~nm}$ aggregates; Fig. 10B). The size of the highest number of attached particles was below $33 \mathrm{~nm}$ for $\mathrm{A} \beta_{1-42}$ treatment 
A
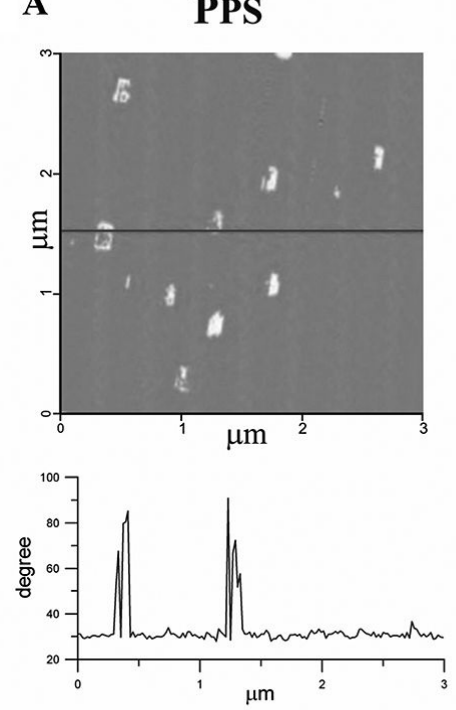

B

B
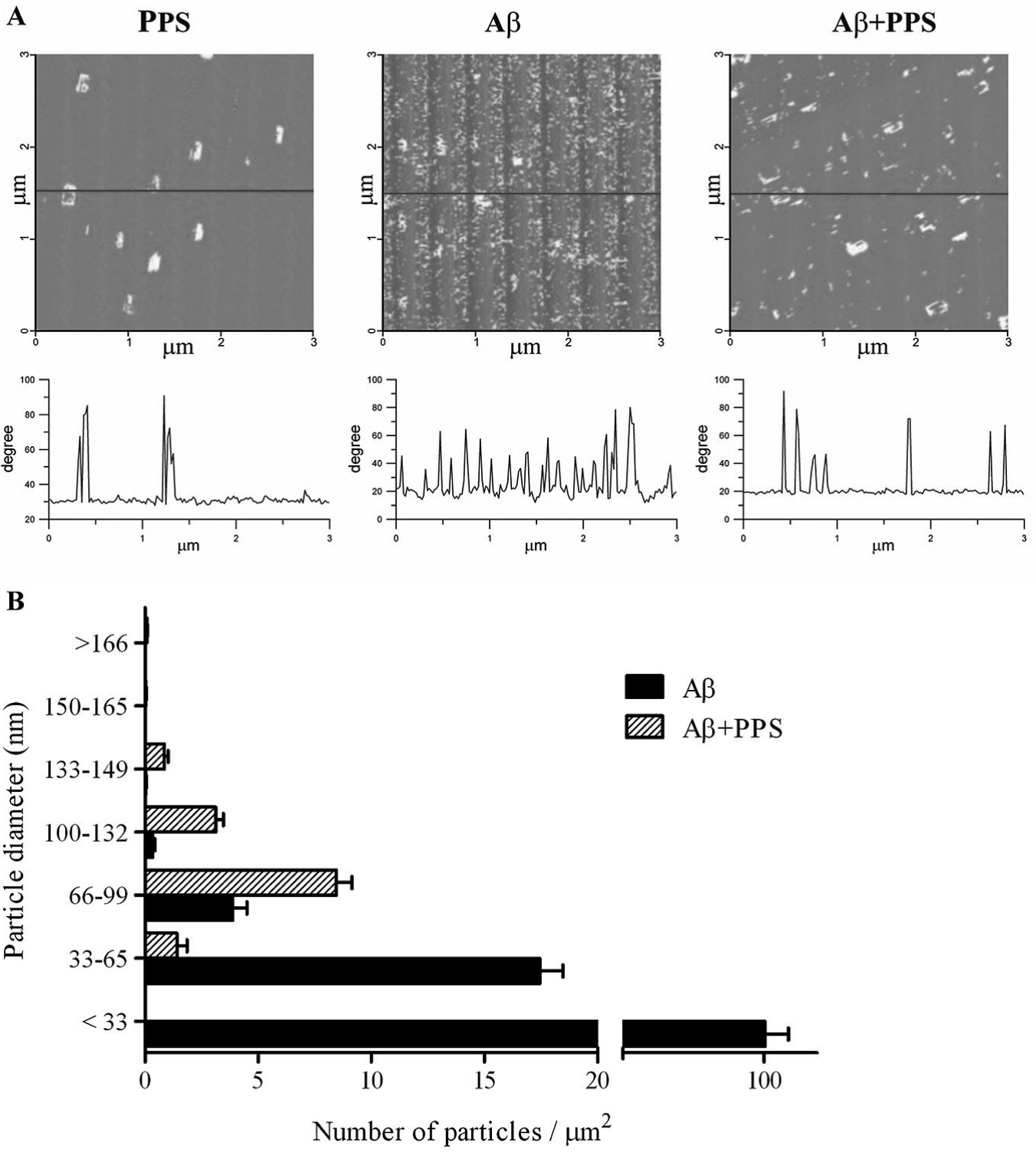

Fig. 10. Atomic force microscopy pictures about the phase of biomolecule aggregates attached to laser-grated polycarbonate surfaces (A). AFM pictures show attachment of pentosan (PPS), amyloid $\beta_{1-42}$ peptide $\left(\mathrm{A} \beta_{1-42}\right)$, and both $\mathrm{A} \beta_{1-42}$ peptide and PPS to the linearly grated surfaces. Concentration of the incubation solutions were $10 \mu \mathrm{g} / \mathrm{ml}$ for $\mathrm{A} \beta_{1-42}$ peptide and $100 \mu \mathrm{g} / \mathrm{ml}$ for PPS. Analysis of the size (largest diameter) and density of the $\mathrm{A} \beta_{1-42}$ peptide aggregates (B) on laser grated surfaces in the absence and presence of pentosan (100 $\left.\mu \mathrm{g} / \mathrm{ml}\right) \mathrm{measured}$ by atomic force microscopy (mean \pm S.E.M., two-way ANOVA followed by Bonferroni test, significant $p<0.001$ differences were found between the two groups).

and 66-99 $\mathrm{nm}$ for $\mathrm{A} \beta_{1-42}$ and PPS treatments $(8.46 \pm$ 0.69 particles $/ \mu \mathrm{m}^{2}$ ).

Grating coupled surface plasmon resonance investigation was performed on biomolecule-covered polymer-bimetal interfacial gratings in a separate experiment [32]. The forward shift of the secondary resonance minima detected on samples treated by $\mathrm{A} \beta_{1-42}$ and PPS was smaller than the shift measured after pure
$\mathrm{A} \beta_{1-42}$ attachment. Since the resonance minima shifts are proportional to changes in dielectric layer thickness, the smaller shift indicates that the PPS therapeutic molecules prevent the adherence of large amount of $\mathrm{A} \beta_{1-42}$ to the examined surfaces. The analyses of the results have shown that in presence of PPS the average thickness of the adhered biomolecule layer is reduced from $4.5 \mathrm{~nm}$ to $3.8 \mathrm{~nm}$. The difference between 
the layer thickness enhancements is significantly larger than the change caused when PPS was applied solely $(-0.2 \mathrm{~nm})$. Both AFM and plasmon resonance experiments prove that PPS can directly interact with $\mathrm{A} \beta_{1-42}$ resulting in decreased adherence.

\section{DISCUSSION}

\section{Changes in blood-brain barrier function and morphology in $A D$}

Recent clinical data indicate that vascular changes play an important role early in AD pathogenesis. Cerebral blood flow (CBF) and cerebral glucose uptake reductions were demonstrated in the early stages of $\mathrm{AD}$ and both low CBF and reduced brain glucose uptake may precede neurodegeneration and contribute to the progression of dementia prior to cerebral atrophy [7]. Positive links and overlap exist between cerebrovascular disorders and AD. Severe atherosclerosis increases threefold the risk of developing AD or vascular dementia [38].

Pathological $\mathrm{A} \beta$ fibrils are deposited both in brain parenchyma and around brain vessels in $\mathrm{AD}[2,4]$. The cerebrovascular amyloidosis or cerebral amyloid angiopathy is a hallmark of the disease, it is present in more than $80 \%$ of AD patients, and is causally involved in the development of neurodegeneration in $\mathrm{AD}[2$, 7]. Accumulation of $\mathrm{A} \beta$ in the wall of cerebral blood vessels and in the brain parenchyma in $A D$ is due to imbalances between its production and clearance from the brain [4]. Several transporters were identified to participate in the transport of $\mathrm{A} \beta$ across the $\mathrm{BBB}$, including receptor for advanced glycation end products (RAGE) [39,40], low-density lipoprotein receptor related protein 1 [41,42] and 2 [43], P-glycoprotein [44], and breast cancer resistance protein (BCRP) [5].

Morphological abnormalities in the cerebral microvasculature in AD include atrophy and irregularities of arterioles and capillaries, swelling and increased number of pinocytic vesicles in endothelial cells, increase in collagen IV, heparan sulfate proteoglycans and laminin deposition in the basement membrane, disruption of the basement membrane, reduced total microvascular density and occasional swelling of astrocytic end feets [7]. An extensive degeneration of brain microvascular endothelium was also demonstrated during the disease progression in $\mathrm{AD}$ [45].

The morphological changes are accompanied by functional alterations, microvascular segments directly surrounded by amyloid plaques or representing cerebral amyloid angiopathy show increased permeability to endogenous albumin [46]. The degree of AD can influence these changes: in mild dementia the integrity of the BBB can be well preserved, while it is disturbed in a graded manner according to the progression of dementia [47]. When $\mathrm{A} \beta_{1-42}$ is directly infused into the carotid artery, it increased permeability to albumin in rats [13]. Using the AD model Tg2576 mice a higher BBB permeability for albumin was measured in cerebral cortex, which preceded senile plaque formation [14]. Even if extensive BBB damage or substantial increases in $\mathrm{BBB}$ permeability in $\mathrm{AD}$ can not be found in some animal studies [48] or clinical evaluations [49], considering all available data focal and transient loss of integrity of the BBB in AD seems probable [50].

\section{Studies with A $\beta$ on culture-based BBB models}

BBB changes in AD were confirmed by experimental data showing the effects of $\mathrm{A} \beta$ on cultured endothelial cells. $\mathrm{A} \beta$ peptides inhibited the proliferation of brain endothelial cells [2]. In addition, $\mathrm{A} \beta$ peptides exerted toxic effects on both peripheral and cerebral microvessel endothelial cells. $\mathrm{A} \beta_{1-40}$ and $\mathrm{A} \beta_{25-35}$ peptide treatments resulted in apoptosis in cultured pulmonary endothelial cells, and elevated the monolayers' albumin permeability [15]. A similar toxicity was described in RBE4 rat brain endothelial cell line [16]. $\mathrm{A} \beta_{1-40}$ and $\mathrm{A} \beta_{1-42}$ peptides derived from rat and human amyloid, alone or complexed with aluminum, decreased cell viability in rat brain endothelial cells between passage 3-4 [17,51]. Aggregates of $\mathrm{A} \beta_{1-40}$, and its mutation $\mathrm{A} \beta_{1-40} \mathrm{E} 22 \mathrm{Q}$ (Dutch), as well as of $\mathrm{A} \beta_{1-42}$ and $\mathrm{A} \beta_{25-35}$ were toxic to cultured human cerebrovascular endothelial cells obtained from the brain of a victim of $\mathrm{AD}$ [52]. The toxic effect of the Dutch $\mathrm{A} \beta$ peptides on BBB is further supported by an in vivo study showing that these mutant peptides are not cleared from CSF [53]. The Akt [54], and protein kinase C [55] signalling pathways, the RAGE [56] and the activation of caspase-8 [57] can participate in the decrease of cell viability and apoptotic cascade induced by $\mathrm{A} \beta$ in endothelial cells.

In our study, $\mathrm{A} \beta_{1-42}$ peptide induced remarkable ultrastructural alterations in primary rat brain endothelial cells, which have not been described in the literature earlier. In agreement with amyloid-induced changes in brain microvessel morphology in pathological samples and animal studies [7,45] degeneration of the cells, namely, dark cytoplasm, pronounced vacuolization, de- 
creased number of caveolae and Golgi, and shrunken mitochondria could be observed after peptide treatment. Irregular interendothelial contacts and junctions with less kissing points were especially notable, indicating an increased paracellular pathway. Cytoplasmic vacuolization could be seen by both electron and phase contrast microscopy. These toxic effects were also confirmed by reduced MTT dye reduction, and increased LDH release indicating plasma membrane damage. In the $\mathrm{A} \beta$ dose-range used in our experiments (10-200 $\mu \mathrm{M})$ endothelial cell death did not exceed $20 \%$. Both $\mathrm{A} \beta_{1-40}$ and $\mathrm{A} \beta_{1-42}$ peptides exerted a similar toxic effect to primary rat brain endothelial cells.

$\mathrm{A} \beta$-induced permeability changes have been studied only for $\mathrm{A} \beta_{1-40}$ and only in not co-cultured brain endothelial cells so far and no data have been published on pertinent co-culture in vitro $\mathrm{BBB}$ model yet. $\mathrm{A} \beta_{1-40}$ at doses exceeding $5 \mu \mathrm{M}$ increased the paracellular permeability in bovine brain endothelial cells [19]. It also induced a marked elevation in the permeability for the paracellular tracer $70 \mathrm{kDa}$ FITC-dextran in an immortalized human brain endothelial cell line, hCMEC/D3 cells [58] and for the transcellular marker albumin in human brain microvascular endothelial monolayers between passages 4-8 [20].

We have studied the effect of $A \beta$ on several aspects of the barrier function in BBB model of rat primary brain endothelial cells, in which barrier properties were induced by glial cells. $\mathrm{A} \beta_{1-42}$ decreased the resistance and increased the permeability for markers fluorescein and albumin. The modulating effect of SAP on $\mathrm{A} \beta$ in a $\mathrm{BBB}$ model was also demonstrated for the first time. SAP, a serum protein belonging to the pentraxin protein family, participates in the regulation of chromatin-induced autoimmunity and the immune defense against bacterial infections due to its ability to bind chromatin and bacterial lipopolysaccharides [59]. SAP treatment alone did not change brain endothelial paracellular permeability or morphology. In a previous in vivo study, when mice were injected with human SAP no deleterious effect on paracellular permeability was noticed [60]. Based on these observations, SAP in physiological concentrations has no effect on brain endothelial TJs. SAP avidly binds amyloid fibrils and can be found in all types of amyloid depositions either in the periphery or in the CNS [61]. While SAP is absent from the brain tissue in physiological conditions, it is present in amyloid plaques and depositions around brain vessels in $\mathrm{AD}$ and contributes to the stabilization of A $\beta$ fibrils [62]. In our experiments, SAP significantly increased the damaging effect of $\mathrm{A} \beta$ on barrier integrity of brain endothelial cells.
Since the paracellular barrier at the BBB is regulated by TJ proteins $[5,8,63,64]$ immunostaining for TJ proteins was also investigated after $\mathrm{A} \beta$ treatment in brain endothelial cells. $\mathrm{A} \beta$ led to fragmentation and loss of junctional immunostaining for occludin, claudin-5 and ZO-1 in our model. These data are in agreement with previous observations, where $\mathrm{A} \beta_{1-42}$ altered occludin, claudin-5 and ZO-2 TJ protein distribution and expression [35], and $\mathrm{A} \beta_{1-40}$ resulted in relocalization of ZO-1 [20] in rat and human brain endothelial cells, respectively. Interestingly, a specific decrease of occludin but not of claudin-5 and ZO-1 was described in an immortalized human brain endothelial cell line [58].

Our data indicate that $\mathrm{A} \beta_{1-40}$ and $\mathrm{A} \beta_{1-42}$ peptides exerted a direct damaging effect on the morphology and barrier integrity of brain endothelial cells which could be aggravated by SAP. Using the same BBB model we have recently confirmed the effect of human truncated tau protein, another pathological factor in AD [65]. Truncated tau also impaired the barrier integrity, but this effect was indirect. Tau-induced BBB damage was mediated by pro-inflammatory cytokine tumor necrosis factor- $\alpha$ and chemokine monocyte chemotactic protein-1 released from activated microglial cells. These observations indicate that while both $\mathrm{A} \beta$ and truncated tau damage the $\mathrm{BBB}$, the underlying mechanisms may be different [65].

\section{Protection of BBB as a New Therapeutical Approach in $A D$}

$\mathrm{AD}$, the most common form of degenerative dementia, represents a huge unmet medical need. Although AD had already been described about 100 years ago, at present only few symptomatic treatment options exist for the more than 25 million patients worldwide despite continuous research efforts. Only two classes of medications have been approved by the US Food and Drug Administration for the treatment of AD: cholinesterase inhibitors for mild to moderate $\mathrm{AD}$, and the noncompetitive NMDA receptor antagonist memantine for the moderate to severe stages of AD [66].

$\mathrm{BBB}$ breakdown, due to disruption of the TJs, altered transport of molecules at the BBB, aberrant angiogenesis, vessel regression, brain hypoperfusion, and inflammatory responses initiate and contribute to a "vicious circle" of the disease process, resulting in progressive synaptic and neuronal dysfunction and loss in AD [5, 67]. This current understanding places the neurovascular unit at the epicenter of AD pathophysiology and recognizes brain endothelial cells as new therapeuti- 
cal targets in AD [5,6]. Since previous therapeutical attempts were focused on the prevention of neuronal death there are a great number of experimental data on the protection of neurons against the toxic effects of $\mathrm{A} \beta$ [68]. In contrast, only few studies examined protective molecules in brain endothelial cells. Partial protection against $\mathrm{A} \beta_{25-35}$ peptide-induced cell damage by carnosine, an endogenous antiglycating dipeptide with free radical scavenging activity, homocarnosine and $\beta$-alanine was described on a rat brain endothelial cell line [16]. Simvastatin effectively blocked the proinflammatory reactions induced by $\mathrm{A} \beta_{1-40}$ peptide in a human brain endothelial cell line [69]. Tauroursodeoxycholic acid, an antiapoptotic endogenous bile acid inhibited the apoptosis of human brain cerebral endothelial cells triggered by the vasculotropic $\mathrm{A} \beta_{1-40}$ E22Q mutant peptide [70]. While apolipoprotein-E4 increased, apolipoprotein-E2 decreased the cytotoxic effect of $\mathrm{A} \beta_{1-40}$ and $\mathrm{A} \beta_{1-42}$ pepides [71]. Recently, the JNK-AP1 signaling pathway [72], transcription factors mesenchyme homebox gene 2 (MEOX-2) [5, 72], and serum response factor and myocardin [73] have been identified as potential therapeutical targets in brain endothelial cells in AD.

PPS, a drug of plant origin used clinically for a long time, protected primary mouse cerebral endothelial cells against prion peptide toxicity $[3,22,23]$ and attenuated both the permeability barrier impairment and inhibition of P-glycoprotein in lipopolysaccharideexposed primary rat brain endothelial cells [24] in our previous experiments.

PPS is excessively sulphated, has a high negative charge density and a rod-like conformation; therefore it competes more effectively with endogenous glycosaminoglycans than most of the polyanions [74]. Since glycosaminoglycans are important regulators in many biologically diverse processes, PPS has a wide range of pharmacological effects $[74,75]$. It has long been used in clinical practice as an anticoagulant [75], and it is effective in the treatment of interstitial cystitis [76], and osteoarthritis [77]. Experimental and clinical data suggest that PPS may also have a therapeutic efficacy in prion disease [78]. Because PPS does not cross the BBB [79], endothelial cells of blood-nerve and blood-brain barriers may be among the cellular targets of PPS in the prevention of prion diseases in vivo $[22,23]$.

In our present and previous studies we demonstrated for the first time that PPS did not change BBB parameters TEER, permeability or fluid phase endocytosis or morphology in cultured brain endothelial cells [18,21,
23 ], but successfully attenuated the toxic effects of $\mathrm{A} \beta$. PPS also protected the barrier integrity of endothelial monolayers treated with $\mathrm{A} \beta$. The exact mode of action of PPS at the BBB has not been elucidated yet.

In other cell types PPS inhibits a wide range of enzymes and biological modulators, like protein kinase A, protein kinase $\mathrm{C}$, tyrosine protein kinase in smooth muscle cells [75], serine proteases, matrix metalloproteinases, lysosomal enzymes, coagulation factors, complement factors and cytokines in chondrocytes [74]. In peripheral endothelial cells PPS stimulates the release of tissue-type plasminogen activator, superoxide dismutase and lipase contributing to its efficacy in arthritis [74]. The inhibition of serine proteases, matrix metalloproteinases and cytokines or increased levels of superoxide dismutase could also contribute to the protection of the BBB; however other actions of PPS could also be important.

Our previous and present surface plasmon resonance and AFM data indicate for the first time that PPS can directly interact with $\mathrm{A} \beta$, and may have a physicochemical effect resulting in fewer adherences to the examined surfaces. This is in agreement with the only study that examined the effect of PPS on the binding of heparan sulfate glycosaminoglycans to A $\beta$ [25]. PPS was the most effective to displace heparan sulfate glycosaminoglycans bound to $\mathrm{A} \beta$. Since heparan sulfate glycosaminoglycans are involved in $\mathrm{A} \beta$ aggregation in vivo, sulfated polyanions, like PPS, can be useful against amyloid deposition in AD brain [25].

Pentosan may exert multiple effects; some of these could be cellular while others could be related to its direct interaction with $\mathrm{A} \beta$. The present results support this dual mode of action and the endothelial protective properties of PPS. Further experiments are needed to fully map the mode of action of pentosan on brain endothelial cells and on its direct interaction with $\mathrm{A} \beta$.

In conclusion, pentosan can represent a new type of molecule to protect brain endothelial cells in pathological conditions, including $\mathrm{A} \beta$ toxicity, and to contribute to the maintenance of brain homeostasis and prevention of neuronal loss.

\section{ACKNOWLEDGMENTS}

Supported by research grants RET 08/2004, OTKA T37834, M36252, GVOP-KMA-52, TÁMOP-4.2.208/1/2008-0002. L.F. wishes to thank the Hungarian Academy of Sciences for the support of the János Bolyai Research Grant.

Authors' disclosures available online (http://www.jalz.com/disclosures/view.php?id=546). 


\section{REFERENCES}

[1] European Commission Health and Consumers DirectorateGeneral, Communication from the Comission to the European Parliament and the Council on a European initiative on Alzheimer's disease and other dementias, COM (2009) $380 \mathrm{fi}-$ nal, http://ec.europa.eu/health/ph_information/dissemination /documents/com2009_380_en.pdf, Brussels, 22.7.2009, access: 07.04.2010.

[2] Grammas P, Yamada M, Zlokovic BV (2002) The cerebromicrovasculature: a key player in the pathogenesis of Alzheimer's disease. J Alzheimers Dis 4, 217-223.

[3] Deli MA (2005) The role of blood-brain barrier in neurodegenerative diseases. In Molecular Bases of Neurodegeneration, Di Liegro I, Savettieri G, eds., Research Signpost, Kerala, India, 2005, pp. 137-161.

[4] Zlokovic BV (2005) Neurovascular mechanisms of Alzheimer's neurodegeneration. Trends Neurosci 28, 202-208.

[5] Zlokovic BV (2008) The blood-brain barrier in health and chronic neurodegenerative disorders. Neuron 57, 178-201.

[6] Jaeger LB, Dohgu S, Hwang MC, Farr SA, Murphy MP, Fleegal-Demotta MA, Lynch JA, Robinson SM, Niehoff ML, Johnson SN, Kumar VB, Banks WA (2009) Testing the neurovascular hypothesis of Alzheimer's disease: LRP-1 antisense reduces blood-brain barrier clearance and increases brain levels of amyloid- $\beta$ protein and impairs cognition. $J$ Alzheimers Dis 17, 553-570.

[7] Bell RD, Zlokovic BV (2009) Neurovascular mechanisms and blood-brain barrier disorder in Alzheimer's disease. Acta Neuropathol 118, 103-113.

[8] Abbott NJ, Rönnbäck L, Hansson E (2006) Astrocyteendothelial interactions at the blood-brain barrier. Nat Rev Neurosci 7, 41-53.

[9] Zlokovic BV, Yamada S, Holtzman D, Ghiso J, Frangione B (2000) Clearance of amyloid $\beta$-peptide from brain: transport or metabolism? Nat Med 6, 718-719.

[10] Forman MS, Trojanowski JQ, Lee VM (2004) Neurodegenerative diseases: a decade of discoveries paves the way for therapeutic breakthroughs. Nat Med 10, 1055-1063.

[11] DeMager PP, Penke B, Walter R, Harkany T, Härtignny W (2002) Pathological peptide folding in Alzheimer's disease and other conformational disorders. Curr Med Chem 9, 17631780 .

[12] Hirschfield GM, Hawkins PN (2003) Amyloidosis: new strategies for treatment. Int J Biochem Cell Biol 35, 1608-1613.

[13] Jancsó G, Domoki F, Sántha P, Varga J, Fischer J, Orosz K, Penke B, Becskei A, Dux M, Tóth L (1998) $\beta$-Amyloid (1-42) peptide impairs blood-brain barrier function after intracarotid infusion in rats. Neurosci Lett 253, 139-141.

[14] Ujiie M, Dickstein DL, Carlow DA, Jefferies WA (2003) Blood-brain barrier permeability precedes senile plaque formation in an Alzheimer disease model. Microcirculation 10, 463-470

[15] Blanc EM, Toborek M, Mark RJ, Hennig B, Mattson MP (1997) Amyloid $\beta$-peptide induces cell monolayer albumin permeability, impairs glucose transport, and induces apoptosis in vascular endothelial cells. J Neurochem 68, 1870-1881.

[16] Preston JE, Hipkiss AR, Himsworth DT, Romero IA, Abbott NJ (1998) Toxic effects of $\beta$-amyloid(25-35) on immortalised rat brain endothelial cell: protection by carnosine, homocarnosine and $\beta$-alanine. Neurosci Lett 242, 105-108.

[17] Folin M, Baiguera S, Tommasini M, Guidolin D, Conconi MT, De Carlo E, Nussdorfer GG, Parnigotto PP (2005) Effects of $\beta$ - amyloid on rat neuromicrovascular endothelial cells cultured in vitro. Int J Mol Med 15, 929-935.

[18] Deli MA, Ábrahám CS, Kataoka Y, Niwa M (2005) Permeability studies on in vitro blood-brain barrier models: physiology, pathology, and pharmacology. Cell Mol Neurobiol 25, 59-127.

[19] Strazielle N, Ghersi-Egea JF, Ghiso J, Dehouck M-P, Frangione B, Patlak C, Fenstermacher J, Gorevic P (2000) In vitro evidence that $\beta$-amyloid peptide 1-40 diffuses across the blood-brain barrier and affects its permeability. J Neuropathol Exp Neurol 59, 29-38.

[20] Gonzalez-Velasquez FJ, Kotarek JA, Moss MA (2008) Soluble aggregates of the amyloid- $\beta$ protein selectively stimulate permeability in human brain microvascular endothelial monolayers. J Neurochem 107, 466-477.

[21] Deli MA, Ábrahám CS, Takahata H, Katamine S, Niwa M (2000) Pentosan polysulfate regulates scavenger receptormediated, but not fluid-phase, endocytosis in immortalized cerebral endothelial cells. Cell Mol Neurobiol 20, 731-745.

[22] Deli MA, Niwa M, Katamine S, Ábrahám CS (1999) Pentosan in transmissible spongiform encephalopathies. Lancet 353, 1272.

[23] Deli MA, Sakaguchi S, Nakaoke R, Ábrahám CS, Takahata H, Kopáček J, Shigematsu K, Katamine S, Niwa M (2000) PrP fragment 106-126 is toxic to cerebral endothelial cells expressing PrPC. Neuroreport 11, 3931-3936.

[24] Veszelka S, Pásztói M, Farkas AE, Krizbai I, Dung NTK, Niwa M, Ábrahám CS, Deli MA (2007) Pentosan polysulfate protects brain endothelial cells against bacterial lipopolysaccharide-induced damages. Neurochem Int 50, 219228.

[25] Leveugle B, Scanameo A, Ding W, Fillit H (1994) Binding of heparan sulfate glycosaminoglycan to $\beta$-amyloid peptide: inhibition by potentially therapeutic polysulfated compounds. Neuroreport 5, 1389-1392.

[26] Zarándi M, Soós K, Fülöp L, Bozsó Z, Datki Z, Tóth GK, Penke B (2007) Synthesis of A $\beta$ [1-42] and its derivatives with improved efficiency. J Peptide Sci 13, 94-99.

[27] Sipos E, Kurunczi A, Fehér A, Penke Z, Fülöp L, Kasza A, Horváth J, Horvát S, Veszelka S, Balogh G, Kürti L, Erõs I, Szabó-Révész P, Párducz A, Penke B, Deli MA (2010) Intranasal delivery of human $\beta$-amyloid peptide in rats: effective brain targeting. Cell Mol Neurobiol 30, 405-413.

[28] Hetényi A, Fülöp L, Martinek TA, Wéber E, Soós K, Penke B (2008) Ligand-induced flocculation of neurotoxic fibrillar A $\beta(1-42)$ by noncovalent crosslinking. ChemBioChem $\mathbf{9}$, 748-757.

[29] Bozso Z, Penke B, Simon D, Laczkó I, Juhász G, Szegedi V, Kasza A, Soós K, Hetényi A, Wéber E, Tóháti H, Csete M, Zarándi M, Fülöp L (2010) Controlled in situ preparation of $\mathrm{A} \beta(1-42)$ oligomers from the isopeptide "iso-A $\beta(1-42)$ ", physicochemical and biological characterization. Peptides 31, 248-256.

[30] Perrière N, Demeuse P, Garcia E, Regina A, Debray M, Andreux JP, Couvreur P, Scherrmann JM, Temsamani J, Couraud P-O, Deli MA, Roux F (2005) Puromycin-based purification of rat brain capillary endothelial cell cultures. Effect on the expression of blood-brain barrier-specific properties. $\mathrm{J} \mathrm{Neu-}$ rochem $\mathbf{9 3}, 279-289$.

[31] Kis B, Deli MA, Kobayashi H, Ábrahám CS, Yanagita T, Kaiya H, Isse T, Nishi R, Gotoh S, Kangawa K, Wada A, Greenwood J, Niwa M, Yamashita H, Ueta Y (2001) Adrenomedullin regulates blood-brain barrier functions in vitro. Neuroreport 12, 4139-4142. 
[32] Csete M, Sipos Á, Kõházi-Kis A, Szalai A, Szekeres G, Matesz A, Csákó T, Osvay K, Bor Z, Penke B, Deli MA, Veszelka S, Schmatulla A, Marti O (2007) Comparative study of submicrometer polymeric dot-arrays, linear and crossed gratings generated by UV laser based two-beam interference as surfaces for AFM and SPR based bio-sensing. Appl Surf Sci 254, 1194-1205.

[33] Klein WL (2002) A $\beta$ toxicity in Alzheimer's disease: globular oligomers (ADDLs) as new vaccine and drug targets. Neurochem Int 41, 345-352.

[34] Hepler RW, Grimm KM, Nahas DD, Breese R, Dodson EC, Acton P, Keller PM, Yeager M, Wang H, Shughrue P, Kinney G, Joyce JG (2006) Solution state characterization of amyloid $\beta$-derived diffusible ligands. Biochemistry 45, 15157-15167.

[35] Marco S, Skaper SD (2006) Amyloid $\beta$-peptide 1-42 alters tight junction protein distribution and expression in brain microvessel endothelial cells. Neurosci Lett 401, 219-224.

[36] Vukic V, Callaghan D, Walker D, Lue LF, Liu QY, Couraud PO, Romero IA, Weksler B, Stanimirovic DB, Zhang W (2009) Expression of inflammatory genes induced by beta-amyloid peptides in human brain endothelial cells and in Alzheimer's brain is mediated by the JNK-AP1 signaling pathway. Neurobiol Dis 34, 95-106.

[37] Gumbleton M, Audus KL (2001) Progress and limitations in the use of in vitro cell cultures to serve as a permeability screen for the blood-brain barrier. J Pharm Sci 90, 1681-1698.

[38] van Oijen M, de Jong FJ, Witteman JC, Hofman A, Koudstaal PJ, Breteler MM (2007) Atherosclerosis and risk for dementia. Ann Neurol 61, 403-410.

[39] Deane R, Du Yan S, Submamaryan RK, LaRue B, Jovanovic S, Hogg E, Welch D, Manness L, Lin C, Yu J, Zhu H, Ghiso J, Frangione B, Stern A, Schmidt AM, Armstrong DL, Arnold B, Liliensiek B, Nawroth P, Hofman F, Kindy M, Stern D, Zlokovic B (2003) RAGE mediates amyloid- $\beta$ peptide transport across the blood-brain barrier and accumulation in brain. Nat Med 9, 907-913.

[40] Giri R, Shen Y, Stins M, Du Yan S, Schmidt AM, Stern D, Kim KS, Zlokovic B, Kalra VK (2000) $\beta$-Amyloid-induced migration of monocytes across human brain endothelial cells involves RAGE and PECAM-1. Am J Physiol Cell Physiol 279, C1772-C1781.

[41] Shibata M, Yamada S, Kumar SR, Calero M, Bading J, Frangione $\mathrm{B}$, Holtzman DM, Miller CA, Strickland DK, Ghiso J, Zlokovic BV (2000) Clearance of Alzheimer's amyloid$\beta_{1-40}$ peptide from brain by LDL receptor-related protein-1 at the blood-brain barrier. J Clin Invest 106, 1489-1499.

[42] Deane R, Wu Z, Sagare A, Davis J, Du Yan S, Hamm K, Xu F, Parisi M, LaRue B, Hu HW, Spijkers P, Guo H, Song X, Lenting PJ, Van Nostrand WE, Zlokovic BV (2004) LRP/amyloid $\beta$-peptide interaction mediates differential brain efflux of $\mathrm{A} \beta$ isoforms. Neuron 43, 333-344.

[43] Calero M, Tokuda T, Rostagno A, Kumar A, Zlokovic B, Frangione B, Ghiso J (1999) Functional and structural properties of lipid-associated apolipoprotein J (clusterin). Biochem J 344, 375-383.

[44] Cirrito JR, Deane R, Fagan AM, Spinner ML, Parsadanian M, Finn MB, Jiang H, Prior JL, Sagare A, Bales KR, Paul SM, Zlokovic BV, Piwnica-Worms D, Holtzman DM (2005) P-glycoprotein deficiency at the blood-brain barrier increases amyloid- $\beta$ deposition in an Alzheimer disease mouse model. J Clin Invest 115, 3285-3290.

[45] Kalaria RN, Hedera P (1995) Differential degeneration of the cerebral microvasculature in Alzheimer's disease. Neuroreport 6, 477-480.
[46] Wisniewski HM, Vorbrodt AW, Wegiel J (1997) Amyloid angiopathy and blood-brain barrier changes in Alzheimer's disease. Ann NY Acad Sci 826, 161-172.

[47] Wada H (1998) Blood-brain barrier permeability of the demented elderly as studied by cerebrospinal fluid-serum albumin ratio. Internal Med 37, 509-513.

[48] Poduslo JF, Curran GL, Wengenack TM, Malester B, Duff K (2001) Permeability of proteins at the blood-brain barrier in the normal adult mouse and double transgenic mouse model of Alzheimer's disease. Neurobiol Dis 8, 555-567.

[49] Bronge L (2002) Magnetic resonance imaging in dementia. A study of brain white matter changes. Acta Radiol Suppl 428, $1-32$.

[50] Starr JM, Farrall AJ, Armitage P, McGurn B, Wardlaw J (2009) Blood-brain barrier permeability in Alzheimer's disease: a case-control MRI study. Psychiatr Res Neuroim 171, 239-241.

[51] Drago D, Folin M, Baiguera S, Tognon G, Ricchelli F, Zatta $\mathrm{P}$ (2007) Comparative effects of A $\beta(1-42)-\mathrm{Al}$ complex from rat and human amyloid on rat endothelial cell cultures. $J$ Alzheimers Dis 11, 33-44.

[52] Eisenhauer PB, Johnson RJ, Wells JM, Davies TA, Fine RE (2000) Toxicity of various amyloid $\beta$ peptide species in cultured human blood-brain barrier endothelial cells: increased toxicity of dutch-type mutant. J Neurosci Res 60, 804-810.

[53] Monro OR, Mackic JB, Yamada S, Segal MB, Ghiso J, Maurer C, Calero M, Frangione B, Zlokovic BV (2002) Substitution at codon 22 reduces clearance of Alzheimer's amyloid- $\beta$ peptide from the cerebrospinal fluid and prevents its transport from the central nervous system into blood. Neurobiol Aging 23, 405-412.

[54] Yin KJ, Lee JM, Chen H, Xu J, Hsu CY (2005) A $325-35$ alters Akt activity, resulting in Bad translocation and mitochondrial dysfunction in cerebrovascular endothelial cells. J Cereb Blood Flow Metab 25, 1445-1455.

[55] Pákáski M, Baláspiri L, Checler F, Kása P (2002) Human amyloid- $\beta$ causes changes in the levels of endothelial protein kinase $\mathrm{C}$ and its alpha isoform in vitro. Neurochem Int 41, 409-414.

[56] Baiguera S, Fioravanzo L, Grandi C, Di Liddo R, Parnigotto PP, Folin M (2009) Involvement of the receptor for advanced glycation-end products (RAGE) in $\beta$-amyloid-induced toxic effects in rat cerebromicrovascular endothelial cells cultured in vitro. Int J Mol Med 24, 9-15.

[57] Folin M, Baiguera S, Fioravanzo L, Conconi MT, Grandi C, Nussdorfer GG, Parnigotto PP (2006) Caspase-8 activation and oxidative stress are involved in the cytotoxic effect of $\beta$ amyloid on rat brain microvascular endothelial cells. Int $\mathrm{J} \mathrm{Mol}$ Med 17, 431-435.

[58] Tai LM, Holloway KA, Male DK, Loughlin AJ, Romero IA (2010) Amyloid- $\beta$-induced occludin down-regulation and increased permeability in human brain endothelial cells is mediated by MAPK activation. J Cell Mol Med 14, 1101-1112.

[59] de Haas CJ (1999) New insights into the role of serum amyloid P component, a novel lipopolysaccharide-binding protein. FEMS Immunol Med Microbiol 26, 197-202.

[60] Veszelka S, Urbányi Z, Pázmány T, Németh L, Obál I, Dung NTK, Ábrahám CS, Szabó G, Deli MA (2003) Human serum amyloid $\mathrm{P}$ component attenuates the bacterial lipopolysaccharide-induced increase in blood-brain barrier permeability in mice. Neurosci Lett 352, 57-60.

[61] Pepys MB (2001) Pathogenesis, diagnosis and treatment of systemic amyloidosis. Philos Trans Royal Soc B: Biol Sci 356, 203-210. 
[62] McGeer EG, Yasojima K, Schwab C, McGeer PL (2001) The pentraxins: possible role in Alzheimer's disease and other innate inflammatory diseases. Neurobiol Aging 22, 843-848.

[63] Virgintino D, Errede M, Robertson D, Capobianco C, Girolamo F, Vimercati A, Bertossi M, Roncali L (2004) Immunolocalization of tight junction proteins in the adult and developing human brain. Histochem Cell Biol 122, 51-59.

[64] Krause G, Winkler L, Mueller SL, Haseloff RF, Piontek J, Blasig IE (2008) Structure and function of claudins. Biochim Biophys Acta 1778, 631-645.

[65] Kovac A, Zilkova M, Deli MA, Zilka N, Novak M (2009) Human truncated tau is using different mechanism from $\beta$ amyloid to damage blood-brain barrier. J Alzheimers Dis $\mathbf{1 8}$, 897-906.

[66] Bassil N, Grossberg GT (2009) Novel regimens and delivery systems in the pharmacological treatment of Alzheimer's disease. CNS Drugs 23, 293-307.

[67] Banks WA, Robinson SM, Verma S, Morley JE (2003) Efflux of human and mouse amyloid $\beta$ proteins $1-40$ and $1-42$ from brain: impairment in a mouse model of Alzheimer's disease. Neuroscience 121, 487-492.

[68] Farr SA, Poon HF, Dogrukol-Ak D, Drake J, Banks WA, Eyerman E, Butterfield DA, Morley JE (2003) The antioxidants alpha-lipoic acid and N-acetylcysteine reverse memory impairment and brain oxidative stress in aged SAMP8 mice. $J$ Neurochem 84, 1173-1183.

[69] András IE, Rha G, Huang W, Eum S, Couraud P-O, Romero IA, Hennig B, Toborek M (2008) Simvastatin protects against amyloid $\beta$ and HIV-1 Tat-induced promoter activities of inflammatory genes in brain endothelial cells. Mol Pharmacol 73, 1424-1433.

[70] Viana RJ, Nunes AF, Castro RE, Ramalho RM, Meyerson J, Fossati S, Ghiso J, Rostagno A, Rodrigues CM (2009) Tauroursodeoxycholic acid prevents E22Q Alzheimer's A $\beta$ toxicity in human cerebral endothelial cells. Cell Mol Life Sci 66, 1094-1104.

[71] Folin M, Baiguera S, Guidolin D, Di Liddo R, Gran- di C, De Carlo E, Nussdorfer GG, Parnigotto PP (2006) Apolipoprotein-E modulates the cytotoxic effect of $\beta$-amyloid on rat brain endothelium in an isoform-dependent specific manner. Int J Mol Med 17, 821-826.

[72] Wu Z, Guo H, Chow N, Sallstrom J, Bell RD, Deane R, Brooks AI, Kanagala S, Rubio A, Sagare A, Liu D, Li F, Armstrong D, Gasiewicz T, Zidovetzki R, Song X, Hofman F, Zlokovic BV (2005) Role of the $\mathrm{MEOX}_{2}$ homeobox gene in neurovascular dysfunction in Alzheimer disease. Nat Med 11, 959-965.

[73] Bell RD, Deane R, Chow N, Long X, Sagare A, Singh I, Streb JW, Guo H, Rubio A, Van Nostrand W, Miano JM, Zlokovic BV (2009) SRF and myocardin regulate LRPmediated amyloid- $\beta$ clearance in brain vascular cells. Nat Cell Biol 11, 143-153.

[74] Ghosh P (1999) The pathobiology of osteoarthritis and the rationale for the use of pentosan polysulfate for its treatment. Semin Arthritis Rheum 28, 211-267.

[75] Maffrand JP, Herbert JM, Bernat A, Defreyn G, Delebasse D, Savi P, Pinot JJ, Sampol J (1991) Experimental and clinical pharmacology of pentosan polysulfate. Semin Thromb Hemost 17, 186-198.

[76] Hwang P, Auclair B, Beechinor D, Diment M, Einarson TR (1997) Efficacy of pentosan polysulfate in the treatment of interstitial cystitis: a meta-analysis. Urology 50, 39-43.

[77] Kumagai K, Shirabe S, Miyata N, Murata M, Yamauchi A, Kataoka Y, Niwa M (2010) Sodium pentosan polysulfate resulted in cartilage improvement in knee osteoarthritis - An open clinical trial. BMC Clin Pharmacol 10, 7.

[78] Dealler S, Rainov NG (2003) Pentosan polysulfate as a prophylactic and therapeutic agent against prion disease. IDrugs 6, 470-478.

[79] Leveugle B, Ding W, Laurence F, Dehouck M-P, Scanameo A, Cecchelli R, Fillit H (1998) Heparin oligosaccharides that pass the blood-brain barrier inhibit $\beta$-amyloid precursor protein secretion and heparin binding to $\beta$-amyloid peptide. $J$ Neurochem 70, 736-744. 